\title{
Sedimentary lipid biogeochemistry of an hypereutrophic alkaline lagoon
}

\author{
J. O. Grimalt, ${ }^{1}$ I. Yruela, ${ }^{2}$ C. Saiz-Jimenez, ${ }^{2}$ J. ToJa, ${ }^{3}$ J. W. De Leeuw, ${ }^{4}$ and J. Albaiges ${ }^{1}$ \\ 'Department of Environmental Chemistry (CID-CSIC), Jordi Girona 18, 08034-Barcelona, Spain \\ ${ }^{2}$ Institute of Natural Resources and Agrobiology (CSIC), PO Box 1052, 41080-Sevilla, Spain \\ ${ }^{3}$ University of Sevilla, Faculty of Biology, Department of Vegetal Biology and Ecology, PO Box 1095, 41080-Sevilla, Spain \\ ${ }^{4}$ Delft University of Technology, Faculty of Chemical Engineering and Materials Science, Organic Geochemistry Unit.
} De Vries van Heystplantsoen 2, 2628 RZ Delft, The Netherlands

(Received February 14, 1990; accepted in revised form June 17, 1991)

\begin{abstract}
A detailed study of the lipid composition of sedimentary and water particulate samples of a dilute alkaline lake (Santa Olalla Lagoon, Guadalquivir Delta, southwestern Spain) has allowed the identification and quantitation of about 300 compounds reflecting predominant inputs of organic matter and very early diagenetic processes. These lipids, dominated by fatty acids ( $80-86 \%)$, account for up to $0.25 \%$ wt. of dry sediment which is consistent with the high eutrophic conditions of the lagoon and suggests a good preservation of the originally produced organic matter. However, the primary lipid compounds, mainly from cyanobacterial origin, are strongly modified. The $C_{30}-C_{32}, 1,13-$ and 1,15-diols constitute the only major group that can be attributed directly to these organisms. The predominant lipids, including the fatty acids, are indicative of intense microbial reworking, namely contributions from gram-positive and gram-negative eubacteria and methanogens. Conversely, the higher plant lipids are better preserved and dominate the aliphatic hydrocarbon fraction.

Hydrogenation and dehydration are two major transformation processes in the sedimentary system being reflected in the transformation of sterols into $5 \alpha(\mathrm{H})$ - and $5 \beta(\mathrm{H})$-stanols and sterenes, and $17 \beta(\mathrm{H}), 21 \beta(\mathrm{H})$-hopan-22-ol into diploptene. Oxidation in the water column seems to involve the partial transformation of sterols into steroid ketones, phytol into 5,9,13-trimethyltetradecanoic acid and two isomeric 3,7,11,15-tetramethyl-17-hexadecanolides, and, possibly, tetrahymanol into gammacer-3-one. Adiantone and bishomohopanoic acid probably result from the partial oxydation of extended polyhydroxyhopanes or the $\mathrm{C}_{30}-\mathrm{C}_{33}$ hydroxyhopanes found in the lagoon waters.
\end{abstract}

\section{INTRODUCTION}

THE UPPER LIMIT OF planktonic photosynthetic activity is found in alkaline lakes (TALLING et al., 1973). Primary production in neutral eutrophic lakes and marine upwelling areas usually ranges between 1,000 and $2,000 \mathrm{mg} \mathrm{C} / \mathrm{m}^{2} \cdot$ day, reaching up to $10,000 \mathrm{mg} \mathrm{C} / \mathrm{m}^{2} \cdot$ day in certain upwelling regions (RYTHER et al., 1971). Alkaline lakes generally exhibit production values between 10,000 and $15,000 \mathrm{mg} \mathrm{C} / \mathrm{m}^{2} \cdot$ day (TALLING et al., 1973) and may amount to more than 20,000 $\mathrm{mg} \mathrm{C} / \mathrm{m}^{2}$ - day (KELTS, 1988). These environments constitute the world's most productive systems (MELACK, 1981) and may have led to the generation of hydrocarbon source rocks (EVANS and KIRKLAND, 1988).

The high $\mathrm{pH}$ of these lakes is a consequence of the high concentration of dissolved sodium carbonate which may result from groundwater wash out of sedimentary formations depleted in calcium and magnesium. Under these conditions, mineral leaching by ion exchange and concentration by evaporation may lead to a shift in the carbon dioxide/bicarbonate/carbonate equilibrium towards carbonate (TINDALL, 1988). These systems act as a trap for atmospheric carbon dioxide (IMHOFF et al., 1979). The dissolved carbonate is a reserve of inorganic carbon for photosynthesis that affords a larger biomass than in the corresponding neutral eutrophic lakes (TALLING et al., 1973). Furthermore, the high pH enhances the solubility of phosphorous which also results in higher productivity (TALLING and TALLING, 1965).
In sodium sulphate-rich environments, alkalinity may originate from the activity of sulphate-reducing bacteria that form bicarbonate from organic carbon sources. The concentration of the dissolved salts by evaporation may also give rise to formation of carbonate-containing brines, provided that no significant amounts of calcium or magnesium are present (ABD-EL-MALEK and RIZK, 1963a,b, and c).

The organisms living in these environments must be alkalitolerant and halophilic which severely limitates the diversity of prokaryotic and eukaryotic species. Cyanobacteria, namely Spirulina spp., currently predominate (GRANT and LONG, 1985). In the presence of sulphur species, high concentrations of phototrophic sulphur bacteria, i.e., Ectothiorhodosphira spp., are found (TINDALL, 1988).

Surprisingly, the characterization of the organic matter present in these lake systems has only been undertaken in a very limited number of studies (DEGENS et al., 1973, 1984), and no information is availablc on the molecular composition of the sedimentary record. With this in mind, we undertook a study of the composition of sedimentary lipids of the Santa Olalla Lagoon, an alkaline hypereutrophic system located in the Guadalquivir Delta, Doñana National Park, southwestern Spain (see Fig. 1). To the best of our knowledge, this is the first study concerned with a detailed qualitative and quantitative analysis of the sedimentary lipids of an alkaline lacustrine environment. Data are discussed in terms of predominant input sources and early diagenetic processes. 


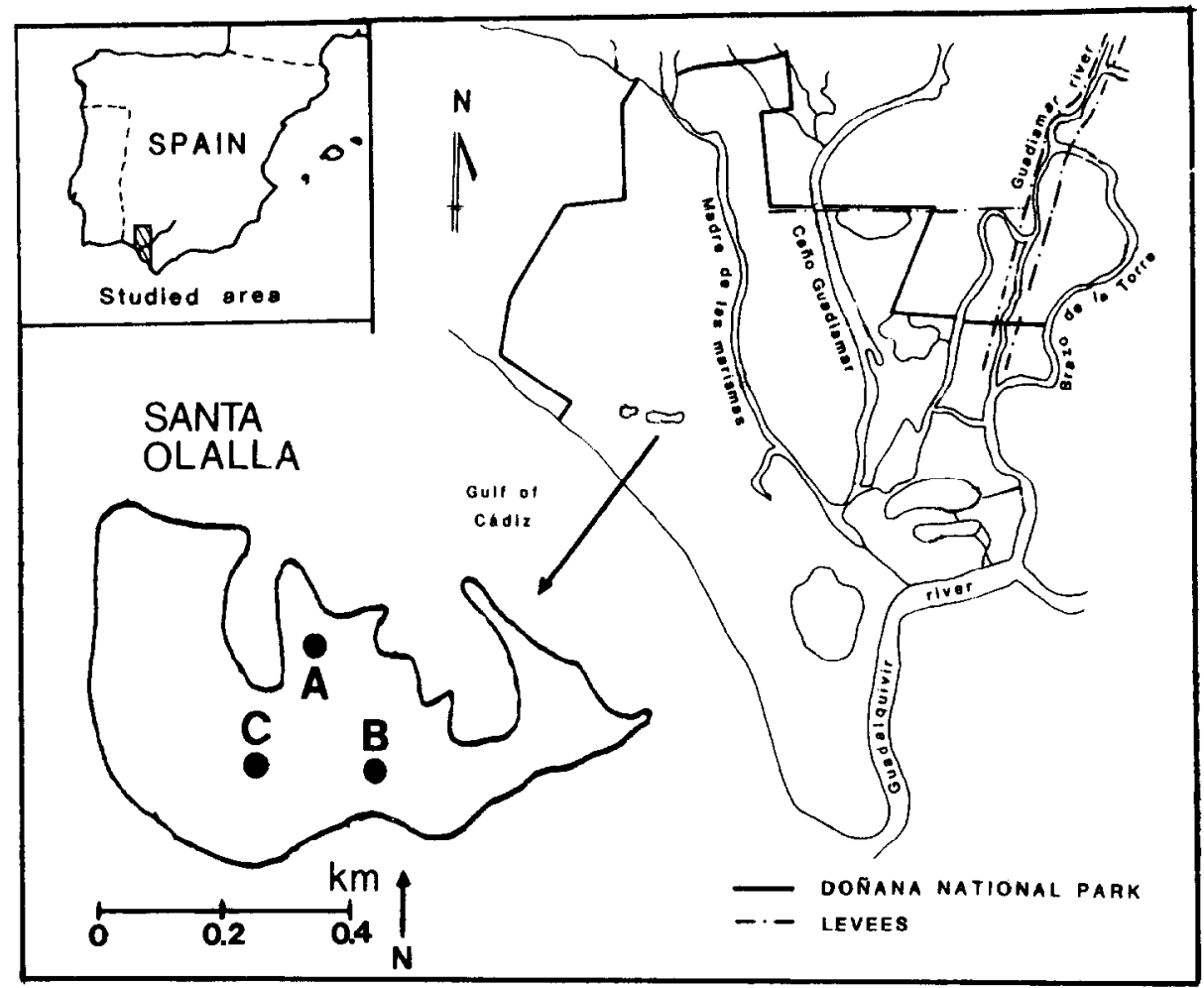

FIG. 1. Map of Santa Olalla Lagoon and surrounding area. Sampling sites are indicated as in Table 1.

\section{MATERIALS AND METHODS}

\section{Water Analysis}

Water samples were collected monthly, from October 1985 to November 1987, at the center of the lagoon. pH (Crison pH meter) and conductivity (YSI conductivimeter) were measured during sampling. Water samples for chemical analysis were stored at $4^{\circ} \mathrm{C}$. The following methods were used: alkalinity (volumetric; GOLTERMAN and CLYMO, 1969), chloride (volumetric, $\mathrm{AgNO}_{3}$ precipitation; APHA, 1980), sulphate (colorimetric; RODIER, 1975), calcium and magnesium (complexometric; APHA, 1980), nitrate (reduction to nitrite through a Cd-Cu column; STRICKLAND and PARSONS, 1972), nitrite (colorimetric; STRICKLAND and PARSONS, 1972), ammonium (nesslerization after precipitation; RODIER, 1975), and reactive soluble phosphorous (colorimetric; MURPHY and RILEY, 1962).

Photosynthetic pigments were determined by filtration through Whatman GF/C glass fibre filters of small water volumes $(<100 \mathrm{~mL})$. The nominal pore size of these filters $(1.2 \mu \mathrm{m})$ was adequate because no photosynthetic organisms smaller than $1.2 \mu \mathrm{m}$ could be observed by microscopic methods. After overnight extraction in cold $\left(4^{\circ} \mathrm{C}\right)$ methanol, the absorbance of the centrifuged extracts was measured spectrophotometrically at 665 and $750 \mathrm{~nm}$. The corrected absorbance at $665 \mathrm{~nm}$ was used to calculate the optically equivalent concentration of chlorophyll- $a$ by the TALLING and DRIVER (1963) and VOLLENWEIDER (1969) methods which correspond to the measurement of the chlorophyll- $a$ plus the phaeophorbide- $a$.

Samples for the study of phytoplankton species were regularly fixed with lugol during water collection. Species identification and counting were accomplished in less than $24 \mathrm{~h}$ after sampling with an inverted optical microscope (Nikon, Diafort) following the technique of UTHERMOLH (1958). In some cases in vivo or formol-fixed samples were examined in addition to the lugol preparations.

\section{Sediment Sampling and Bulk Analyses}

Sediments were taken by gravity coring and stored at $-20^{\circ} \mathrm{C}$. Before analysis they were cut into $3 \mathrm{~cm}$ sections, freeze-dried, and sieved through $250 \mu \mathrm{m}$. Aliquots of the sediments treated with $0.2 \mathrm{~N} \mathrm{HCl}$ for the removal of carbonate were analyzed for organic carbon using a Carlo Erba instrument Model 1106.

\section{Lipid Extraction and Fractionation}

Molecular lipid analysis was performed by Soxhlet extraction of homogenized sediments $(30 \mathrm{~g})$ with $150 \mathrm{~mL}$ of dichloromethanemethanol $(2: 1)$ for $36 \mathrm{~h}$. The extract was vacuum evaporated to 2 $\mathrm{mL}$ and hydrolyzed overnight with $35 \mathrm{~mL}$ of $6 \% \mathrm{KOH} / \mathrm{MeOH}$. The corresponding neutral and acidic fractions were successively recovered with $n$-hexane $(3 \times 30 \mathrm{~mL})$, the latter after acidification $(\mathrm{pH} 2)$ with aq. $6 \mathrm{~N} \mathrm{HCl}$. The acidic fractions, previously reduced to $0.5 \mathrm{~mL}$, were esterified overnight with $15 \mathrm{~mL}$ of $10 \% \mathrm{BF}_{3} / \mathrm{MeOH}$. The boronmethanol complex was destroyed with $15 \mathrm{~mL}$ of water and the fatty acids recovered as methyl esters by extraction with $3 \times 30 \mathrm{~mL}$ of $n$-hexane. The neutral lipids were fractionated by column chromatography using a column filled with $8 \mathrm{~g}$ of each $5 \%$ water deactivated alumina (70-230 mesh, Merck) (top) and silica (70-230 mesh, Merck) (bottom). The following fractions were collected: (I) $20 \mathrm{~mL}$ of $n$-hexane, (II) $20 \mathrm{~mL}$ of $10 \%$ dichloromethane in $n$-hexane, (III) 40 $\mathrm{mL}$ of $20 \%$ dichloromethane in $n$-hexane, (IV) $40 \mathrm{~mL}$ of $25 \% n$ hexane in dichloromethane, (V) $20 \mathrm{~mL}$ of $5 \%$ methanol in dichloromethane, and (VI) $40 \mathrm{~mL}$ of $10 \%$ methanol in dichloromethane. Fraction V and VI were derivatized prior to instrumental analysis by silylation (bis(trimethylsilyl)trifluoroacetamide, $100 \mu \mathrm{L}, 80^{\circ} \mathrm{C}$, $30 \mathrm{~min}$ ).

\section{Derivatization of Unsaturated Components}

Structural determination of double bond positions and the geometry of unsaturated molecules was performed by derivatization of aliquots of selected lipid fractions, namely hydrocarbons, fatty acids, and alcohols. Methods for the formation of epoxides and dimethyl disulphide (DMDS) adducts were used as follows. 


\section{Formation of epoxides}

The fractions were dissolved in dichloromethane $(50 \mu \mathrm{L})$ and treated with $150 \mu \mathrm{L}$ of $m$-chloroperbenzoic acid solution $(0.26 \mathrm{M}$ in dichloromethane). The reaction was carried out in a $2 \mathrm{~mL}$ vial closed with a Teflon-lined cap. The mixture was stirred in an ultrasonic bath for $10 \mathrm{~min}$ and allowed to react overnight in the dark. The resulting solution was concentrated under a stream of nitrogen and submitted to instrumental analysis.

\section{Formation of DMDS adducts}

The fractions (1-300 $\mathrm{mg}$ ) were dissolved in carbon disulphide (1 $\mathrm{mL}$ ) and treated with $1 \mathrm{~mL}$ of DMDS and $100 \mu \mathrm{L}$ of iodine solution ( $58 \mathrm{mg}$ of $\mathrm{I}_{2}$ in $1 \mathrm{~mL}$ of diethyl ether). The reaction was carried out in $5 \mathrm{~mL}$ tubes closed with a Teflon-lined cap and kept at $60^{\circ} \mathrm{C}$ for $24 \mathrm{~h}$. After reaction, $2 \mathrm{~mL}$ of $n$-hexane were added and the excess of iodine was eliminated with $\mathrm{Na}_{2} \mathrm{~S}_{2} \mathrm{O}_{3}$ solution ( $5 \%$ in distilled water). The mixture was vigorously shaken until decoloration. The organic layer was removed with a Pasteur pipette and the aqueous phase was extracted further with $n$-hexane $(2 \times 1 \mathrm{~mL})$. The three organic extracts were combined and concentrated to $100 \mu \mathrm{L}$ under a stream of nitrogen.

\section{Instrumental Analysis}

Gas chromatography (GC) was performed with a Carlo Erba FTV $4160 \mathrm{GC}$ instrument equipped with a flame ionization detector and a splitless injector. A $25 \mathrm{~m} \times 0.25 \mathrm{~mm}$ i.d. column coated with CPSil 8 CB (Chrompack) was used (film thickness $0.13 \mu \mathrm{m}$ ). Hydrogen was the carrier gas $\left(50 \mathrm{~cm} \cdot \mathrm{s}^{-1}\right)$. The oven temperature was programmed from 60 to $300^{\circ} \mathrm{C}$ at $6^{\circ} \mathrm{C} \cdot \mathrm{min}^{-1}$. Injector and detector temperatures werc, respectively, 300 and $330^{\circ} \mathrm{C}$. The injection was in the splitless mode (solvent, iso-octane, hot needle technique) keeping the split valve closed for $35 \mathrm{~s}$.

GC coupled to mass spectrometry (GC-MS) was performed with a Hewlett-Packard 5995 instrument equipped with an HP 300 data system. A column of $25 \mathrm{~m} \times 0.2 \mathrm{~mm}$ i.d. coated with HP- 5 (HewlettPackard) was used (film thickness $0.11 \mu \mathrm{m}$ ). Helium was used as carrier gas. The oven temperature was programmed from 60 to $300^{\circ} \mathrm{C}$ at $4^{\circ} \mathrm{C} \cdot \mathrm{min}^{-1}$. Injection conditions $\left(300^{\circ} \mathrm{C}\right)$ were the same as described above. MS temperatures were: transfer line $300^{\circ} \mathrm{C}$, ion source $200^{\circ} \mathrm{C}$, and analyzer $230^{\circ} \mathrm{C}$. Data were acquired in the electron impact mode $(70 \mathrm{eV})$, scanning between $50-650$ at $1 \mathrm{~s}$ per decade.

\section{Quantitation}

Quantitation was performed from the GC traces. In the case of the mid-chain substituted $n$-alcohols, the contribution of each positional isomer to the GC peak of the corresponding homolog was determined by mass fragmentography using specific ions.

An external standard containing $n$-tetradecane, $n$-docosane, $n$-dotriacontane, and $n$-hexatriacontane was generally used. A standard of $5 \alpha(\mathrm{H})$ - and $5 \beta(\mathrm{H})$-cholestan-3-one was used for the stanones. Alcohols and sterols were quantitated using a standard of $n$-docosanol, $5 \beta(\mathrm{H})$-cholestan-3 $\beta$-ol, $5 \alpha(\mathrm{H})$-cholestan-3 $\beta$-ol, and 24-ethylcholest5 -en-3 $\beta$-ol. The concentrations of fatty acids were determined by comparison with a standard of $n$-heptadecanoic and $n$-heneicosanoic methyl esters. Samples and standards were repeatedly injected until less than 5\% dispersion was observed in the measured areas.

\section{RESULTS AND DISCUSSION}

Santa Olalla Lagoon belongs to the pond system located near the dunes of the E-W coastline of the Guadalquivir Delta (Fig. 1). This lagoon is of Holocene origin (GRANADOS et al., 1988), and its hydrologic regime depends on direct rainfall, run-off, and water table oscillations. The average water level changes from $1.9 \mathrm{~m}$ (spring) to $0.2 \mathrm{~m}$ (fall). This shallow water column combined with wind action prevents density stratification and enhances sediment resuspension. Repeated oxygen determinations have shown that most of the water column is oxic, with a permanent anoxic water layer of $4-5 \mathrm{~cm}$ situated above the underlying sediment.

The origin of Santa Olalla waters is continental. Climatic and topographic factors promote the transport of soluble salts and nutrients from the surrounding soil into the lagoon where they become concentrated. The low calcium and magnesium in the area leads to a shift towards carbonate accumulation in the water column, involving an increase of dissolved inorganic carbon and $\mathrm{pH}$. The overall process results in a mesohaline hypereutrophic alkaline lagoon (KELTS, 1988) where the high pH values (average 9.3, sd 0.74 ) are related to photosynthetic production (see Fig. 2).

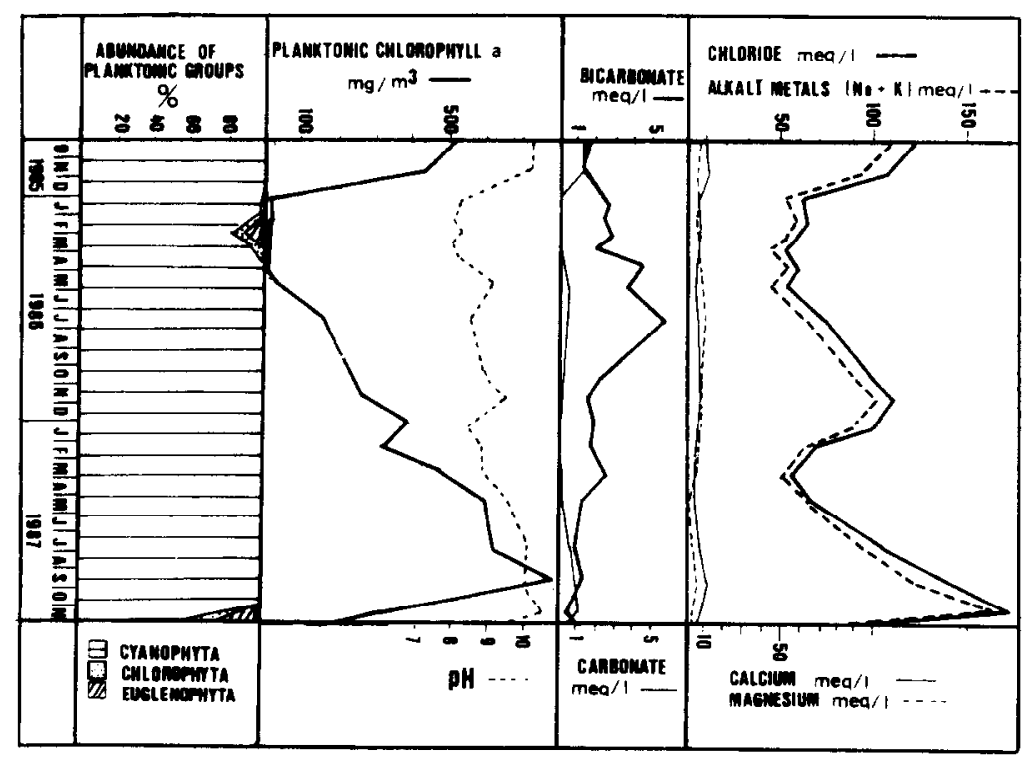

FiG. 2. Main dissolved ions, pH, productivity, and major phytoplankton groups in the waters of Santa Olalla Lagoon. 
As in other alkaline hypereutrophic lakes (TALLING et al., 1973; IMHOFF et al, 1979), dense populations of cyanobacteria are found $\left(10^{6}-10^{7}\right.$ cells $\left./ \mathrm{mL}\right)$, usually representing $99 \%$ of the total phytoplankton biomass (see Fig. 2). Spirulina platensis constitutes the dominant species; at $\mathrm{pH}>10$ this organism is found as an almost pure culture. Spirulina spp. are also the predominant photosynthesizers in many other alkaline lakes (GRANT and LONG, 1985). Other cyanobacteria identified in the Santa Olalla Lagoon include Anabaenopsis circularis, A. tanganyikae, Aphanothece clathrata, Coelosphaerium kuetzingianum, and Microcystis aeruginosa. Most of these species have also been identified in other alkaline lakes (TINDALL, 1988).

In episodic cases, strong rainfall may cause an important salt dilution, resulting in a decrease of planktonic productivity and $\mathrm{pH}$ values (see the period between January 1986 and April 1986 in Fig. 2). In these cases, other photosynthesizers, chlorophyta, or euglenophyta (Trachelomonas spp.) may grow in addition to the predominant cyanobacteria. No submersed macrophytes are found in Santa Olalla sediments, although some filamentous algae (Cladophora sp., Oedogonium sp., and Spirogyra varians) have sporadically been observed in connection with these dilution episodes (TolA et al., 1991).

\section{Organic Bulk Composition of Sediments and Water Particulates}

The average lithology of Santa Olalla sediments corresponds to black sand (74\%), silt ( $22 \%$ ), and a low proportion of clay ( $4 \%$ ), the finer materials being more abundant at the central part of the lagoon where sediments become sandysilty. The total organic carbon (TOC) ranges between 3.5 and $9 \%$, showing a geographical distribution that parallels the grain-size lithology, e.g., maximum values towards the center. These high TOC contents, and consequently high proportion of sedimentary lipid material, are also consistent with the high rate of photosynthetic production of the overlying waters.

One water particulate sample and four sediment core sections, three corresponding to surface levels (sites A, B, C; Fig. 1) and one to a depth of $14-16 \mathrm{~cm}$ (site $C$ ), have been selected for lipid analysis (Table 1). The most distinctive feature of these samples is the high percentage of free and esterified fatty acids, representing about $79-86 \%$ of the total lipids amenable to GC analysis. Free and esterified alcohols, the second fraction in terms of abundance, represent $6-17 \%$, while the hydrocarbons amount to only $2-7 \%$. In principle, the high proportion of sedimentary fatty acids, (i.e., fatty acid:sterol ratio of 10:1) suggests a good preservation of the original biogenic inputs (RHEAD et al., 1977). Furthermore, the high concentration of these fatty acids is consistent with the high productivity of the lagoon (BARNES and BARNES, 1978).

\section{Acyclic Non-Isoprenoid Compounds}

Fatty acids

Representative chromatograms of the fatty acid composition of sediments and water particulates from the Santa Olalla Lagoon are displayed in Fig. 3. Peak identifications and concentration ranges are given in Table 2 . These fatty
Table 1. Bulk parameters of the organic matter from Santa 0lalla samples.

\begin{tabular}{|c|c|c|c|c|c|}
\hline & WATEF & & SEDII & MENTS & \\
\hline & $\mathrm{CW}$ & A & B & $\mathrm{C} 1$ & $\mathrm{C} 2$ \\
\hline Total Organic Carbon ( $\%$ & & 3.5 & 9.0 & 8.5 & 6.3 \\
\hline LIPIDS & $\mathrm{ug} / 1$ & & & $g / g$ & \\
\hline Total lipids & 243 & 1200 & 2500 & 2500 & 1200 \\
\hline Fatty acids & 210 & 1000 & 2100 & 2100 & 950 \\
\hline saturated & 105 & 670 & 1400 & 1400 & 684 \\
\hline unsaturated & 100 & 320 & 640 & 710 & 350 \\
\hline Alcohols & 15 & 130 & 270 & 330 & 200 \\
\hline acyclic & 10 & 62 & 130 & 200 & 120 \\
\hline sterols & 4.8 & 66 & 140 & 134 & 75 \\
\hline Hydrocarbons & 18 & 56 & 80 & 58 & 67 \\
\hline saturated & 11 & 30 & 44 & 3.3 & 54 \\
\hline unsaturated & 5.8 & 24 & 34 & 24 & 13 \\
\hline aromatic & & 0.80 & 0.90 & 0.6 & 0.48 \\
\hline Methoxytriterpanes & & 2.8 & 4.9 & 5.0 & 3.1 \\
\hline Ketones & 0.48 & 0.44 & 0.80 & 0.63 & 0.49 \\
\hline Thiophenes & & 0.42 & 0.60 & 0.55 & 0.06 \\
\hline
\end{tabular}

a) Sampling sites are indicated in Fig. 1, A, B and

C1, surface sediments; $\mathrm{C2}_{2}, 14-16 \mathrm{~cm}$ core section;

CW, water particulates. b) Calculated from total

GC resolved peaks

acid mixtures encompass both the free and esterified components. They are dominated by $\mathrm{C}_{14}-\mathrm{C}_{18} n$-alkanoic and $n$-alkenoic acids with even over odd carbon number preferences. Fatty acids from cyanobacteria usually contain octadecadienoic and/or octadecatrienoic $\left(\Delta^{6,9,12}\right.$ or $\left.\Delta^{9,12,15}\right)$ acids in a proportion up to $40 \%(\sim 20-25 \%$ in $S$. platensis; REZANKA et al., 1983). In Santa Olalla sediments no traces of triunsaturated octadecenoic acids have been found, and only small amounts of octadecadienoic acids have been recognized ( $\sim 0.7 \%$; see Table 2 ). However, both water particulates and sediments exhibit a high proportion of hexadecenoic and octadecenoic acids. Thus, the $16: 1 / 16: 0$ and $18: 1 / 16: 0$ ratios are in the order of $1-1.2$ in the sediments and $\sim 0.5$ in the particulate matter, whereas in cyanobacteria they generally range between 0.2 and 0.3 (in S. platensis, $0.2-0.3$ and $0.1-$ 0.2 for $16: 1 / 16: 0$ and 18:1/16:0, respectively). Variations in nutrient supply do not significantly alter the unsaturated fatty acid composition of cyanobacteria (PIORRECK and POHL, 1984; PIORRECK et al., 1984), so that the differences between Santa Olalla samples and the presumed cyanobacterial precursors must reflect other sources or processes.

The fatty acid composition of many algae contains large amounts of $n$-hexadec- $9(Z)$-enoic and $n$-octadec- $9(Z)$-enoic acids (CHUECAS and RILEY, 1969). However, in the Santa Olalla Lagoon, the unsaturated octadecenoic acids are predominated by $n$-octadec-11(Z)-enoic acid, an isomer characteristic of many gram-negative eubacteria (OLIVER and ColwELL, 1973). This compound is synthesized by $C_{2}$ elongation of shorter chain monounsaturated acids (SCHEUERBRANDT and BLOCH, 1962; WoOD et al., 1965). Thus, the high content of $n$-hexadec- $9(Z)$-enoic acid in these samples is likely associated with the microbial production of $n$-octadec$11(Z)$-enoic acid. $n$-Octadec- $9(Z)$-enoic acid may be a side product of this synthetic pathway (SCHEUERBRANDT and BLOCH, 1962). However, bacteria may also produce this compound and other $\Delta^{9}$ monounsaturated fatty acids by desaturation of the corresponding $n$-alkanoic acids (FULCO et al., 1964). Besides the predominant cis double bond geometry, 

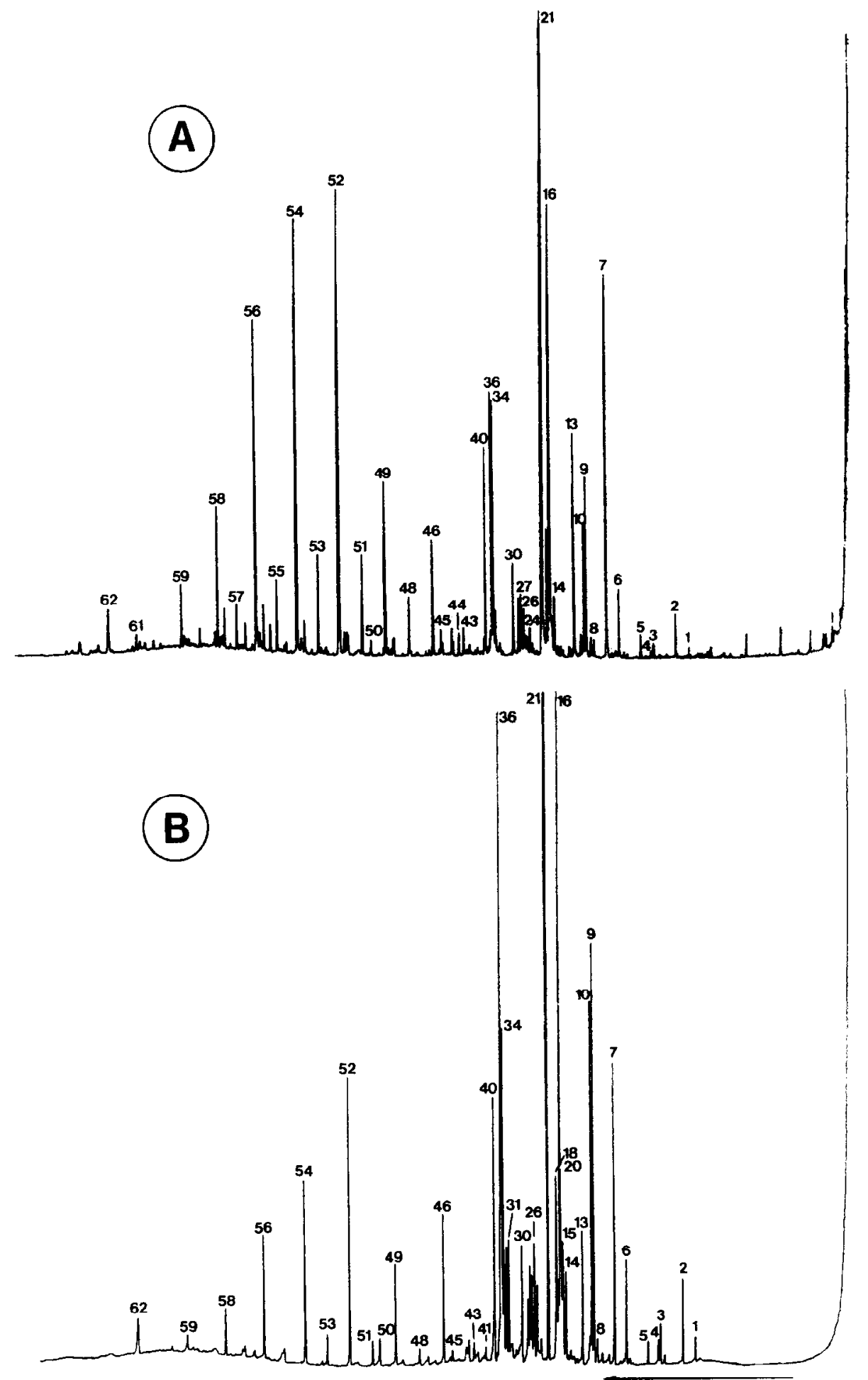

FlG. 3. Representative chromatograms of the fatty acid fractions of Santa Olalla water particulates (A) and sediments (B). Peak identifications are in Table 2.

the occurrence of small amounts of trans $n$-alkenoic acids may reflect contributions from either aerobic gram negative eubacteria (GILLAN et al., 1983) or methane or methanol utilizing bacteria (MAKULA, 1978; GILLAN and SANDSTROM, 1985). Microbial hydrogenation of polyunsaturated acids can also represent a source of trans monounsaturated fatty acids (EYSSEN and VERHULST, 1984). Finally, the presence of $n$-hexadec-10-enoic acid may be indicative of contributions from Mycobacteria (SCHEUERBRANDT and BLOCH, 1962; HUNG and WALKER, 1970). 


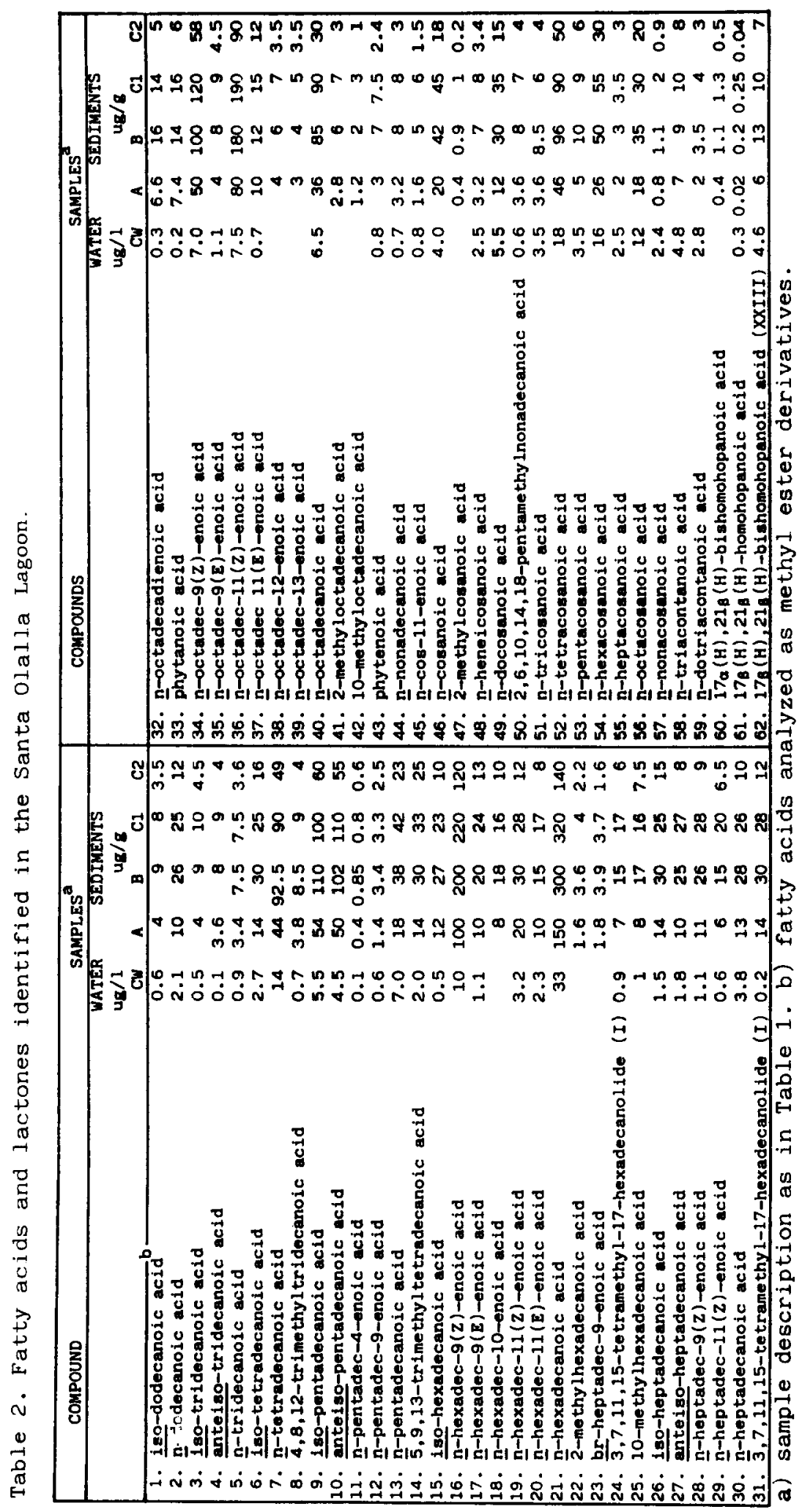



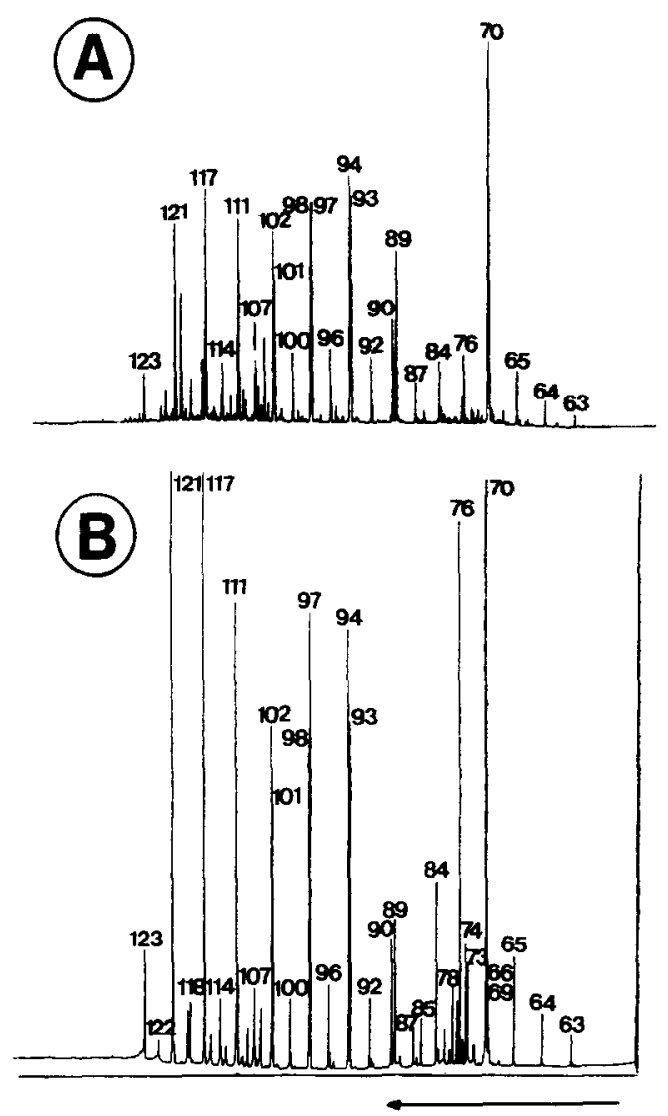

FIG. 4. Representative chromatograms of the F1 hydrocarbon fractions of Santa Olalla water particulates (A) and sediments (B). Peak identifications are in Table 3.

The predominant bacterial origin of Santa Olalla fatty acid distributions is also reflected in the high proportion of isoand anteiso-pentadecanoic acids and other branched homologues, namely iso- and anteiso-tridecanoic acids, and isododecanoic, tetradecanoic, and hexadecanoic acids, that are commonly found in gram-positive eubacteria ( $\mathrm{CHO}$ and SALTON, 1966; KANEDA, 1967). Other methyl-branched fatty acids identified in this lagoon are also characteristic of microbial sources, namely 10-methyl hexadecanoic and octadecanoic acids (fungi: BALLIO and BARCELLONA, 1971; CERNIGLIA and PERRY, 1974; and Mycobacteria: JULAK et al., 1980), and 2-methyl substituted alkanoic acids (Mycobacteria: JULAK et al., 1980). The high proportion of iso- and anteiso-pentadecanoic acids and $n$-octadec-11(Z)-enoic acid provide an evident microbial signature, particularly well defined in the sediments (Fig. 3). However, the particulate fatty acids are also far closer to the composition reported for lacustrine microbial mixtures (MATSUDA and KOYAMA, 1977) than to the above indicated cyanobacterial fatty acid distributions. A considerable degree of microbial reworking has obviously occurred in the water column.

Another group of straight-chain fatty acids present in Santa Olalla sediments and water particulates consists of a distribution of even carbon numbered $\mathrm{C}_{10}-\mathrm{C}_{32}$ saturated homologs. These are constituents of cuticular waxes of higher plants (KolatTUKUDY, 1970), and their occurrence in aquatic environments is usually associated with terrestrial contributions
(FARRINGTON and QUINN, 1973). The presence of higher plant lipids is a general feature of lacustrine sediments from temperate regions which is observed irrespective of the depositional conditions.

\section{Hydrocarbons}

Representative chromatograms of the hydrocarbons present in the sediment and water particulate extracts are displayed in Figs. 4 and 5. Peak identifications and concentration ranges are given in Tables 3 and 4 .

$n$-Heptadecane is the dominant hydrocarbon in both sediment and water particulates, a compound that usually represents algal contributions (CLARK and BLUMER, 1967; HAN et al., 1968). Another important component in the sediments is $n$-octadecane, the most abundant hydrocarbon in many yeast and bacterial species (HAN and CALVIN, 1969; BIRD and LYNCH, 1974; HAN et al., 1968). Besides these two $n$-alkanes, a number of hydrocarbons are also indicative of autochthonous inputs. Thus, the linear and branched $\mathrm{C}_{17}-$ $\mathrm{C}_{20}$ monounsaturated olefins are common in algae and cyanobacteria (HAN and CALVIN, 1969; GELPI et al., 1968) and

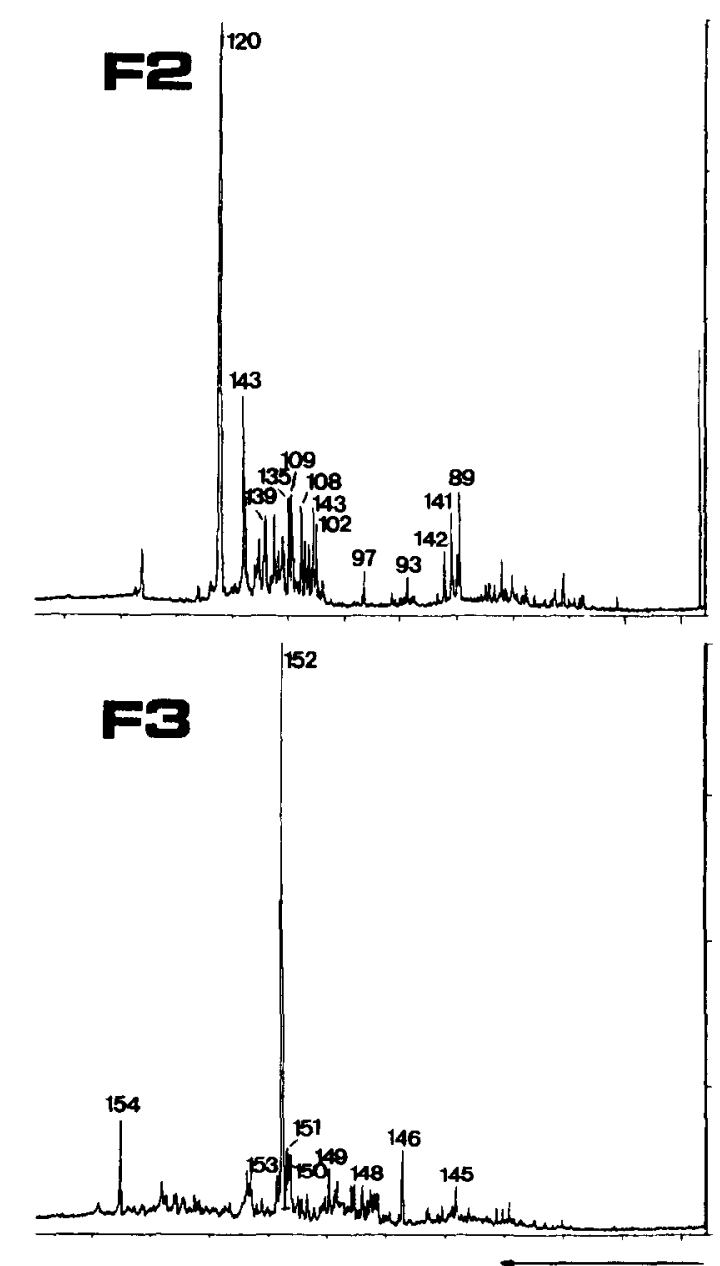

FIG. 5. Representative chromatograms of the hydrocarbon fractions F2 and F3 of Santa Olalla sediments. Peak identifications are in Table 4. 
Table 3. Hydrocarbons identified in fraction FI of Santa Olalla sample extracts.

\begin{tabular}{|c|c|c|c|c|c|c|c|c|c|c|c|}
\hline COMPOUND & & SAM & PLES $^{\text {a }}$ & & & COMPOUND & & SAMPL & $\mathrm{ES}^{\mathrm{a}}$ & & \\
\hline & $\begin{array}{l}\text { WATEl } \\
\mathrm{ug} / 1\end{array}$ & & & $\begin{array}{l}\text { DHWLN } \\
\mathrm{ng} / \mathrm{g}\end{array}$ & & & $\begin{array}{l}\text { ThYtat } \\
\text { ug/I }\end{array}$ & & $\begin{array}{r}\text { SEDI } \\
n\end{array}$ & $\begin{array}{l}\text { MaNrS } \\
\mathrm{g} / \mathrm{a}\end{array}$ & \\
\hline & Cw & $\mathbf{A}$ & $\mathbf{B}$ & $\mathrm{Cl}_{1}$ & $\mathrm{C2}$ & & CW & $\mathbf{A}$ & B & $\mathrm{Cl}_{1}$ & $\mathrm{C} 2$ \\
\hline 63. n-tetradecane & 0.8 & 12 & 37 & 50 & 10 & 94. n-tricosane & 10 & 1900 & 2800 & 1900 & 3000 \\
\hline 64. $\bar{n}$-pen & 1.2 & 100 & 180 & 300 & 120 & 95. $\bar{n}$-tetracos-1-ene & 0.7 & 70 & 180 & 200 & 150 \\
\hline 65. $n$-hexadecene & 2.3 & 300 & 400 & 850 & 350 & 96. n-tetracosane & 3.2 & 360 & 690 & 700 & 800 \\
\hline 66. $\bar{n}$-heptadec $-3(z)$-ene & & 20 & 30 & 40 & 15 & 97. $\bar{n}$-pentacos-1-ene ${ }^{b}$ & 9.5 & 3000 & 4700 & 1850 & 1000 \\
\hline 67. $\bar{n}$-heptadec-3(E)-ene & & 7 & 10 & 10 & 5 & 98. $\overline{\mathbf{n}}$-pentacosane & 9.2 & 1500 & 2900 & 1750 & 3000 \\
\hline 68. br-heptadec-1-one & & 5 & 7 & 10 & 4 & 99. $\bar{n}$-hexacos-1-ene & 0.9 & 100 & 230 & 300 & 100 \\
\hline 69. n-heptadec-1-ene & & 5 & 7 & 12 & 4 & 100. $\bar{n}$-hexacosane & 3.2 & 400 & 760 & 700 & 800 \\
\hline 70. $\bar{n}$-heptadecane & 15 & 4400 & 7900 & 6000 & 8500 & 101. $\bar{n}$-heptacos-1-ene & 6.5 & 1500 & 3700 & 1000 & 700 \\
\hline 71. $\overline{7}$-methy lheptadecane & & 50 & 60 & 100 & 40 & 102. n-heptacosane & 8.7 & 2000 & 3700 & 1800 & 3200 \\
\hline 72. 6-methy lheptadecane & & 57 & 80 & 80 & 50 & 103. choles ta-3,5-diene (XVIIa) & & 560 & 1200 & 750 & 600 \\
\hline 73. 2-methy Iheptedecane & & 220 & 240 & 270 & 200 & 104. wothylbrenched hydrocarbon & & 320 & 800 & 700 & 150 \\
\hline 74. 3-methylheptadecane & & 260 & 300 & 240 & 200 & 105. why thranched hydrocarbon & & 50 & 120 & 100 & 60 \\
\hline 75. phyt-1-ene & & 110 & 170 & 160 & 100 & 106. n-octacos-1-one & 2.4 & 100 & 270 & 250 & 150 \\
\hline 76. n-octadecane & 2.7 & 700 & 1200 & 1500 & 1600 & 107. $\bar{n}$-octacosane & 2.0 & 440 & 920 & 900 & 4000 \\
\hline 77. phyt & 1.3 & 200 & 290 & 400 & 300 & 108. cholest-2-ene (XVIa) & 0.8 & 560 & 1100 & 800 & 600 \\
\hline 78. phyt-2(20)-ene & & 200 & 340 & 320 & 120 & 109. 22,29,30-trienorhop-17(21)-ene (XXIIIa) & 0.7 & 360 & 500 & 450 & 200 \\
\hline 79. phyt-2-ene & & 100 & 160 & 140 & 60 & 110. n-nonacos-1-ene & 5.2 & 500 & 920 & 400 & 600 \\
\hline 80. phytadiene & & 100 & 170 & 150 & 80 & 111. n-nonacosane & 8.9 & 2600 & 5300 & 2000 & 6000 \\
\hline 81. n-nonadec-3(z)-ene & & 10 & 15 & 14 & 7 & 112. $\overline{2} 4$-ethylcholes ta-N,22-diene ${ }^{b}$ (XVIIIc) & & 440 & 610 & 550 & 700 \\
\hline 82. $\bar{n}$-nonadec-3(E)-ene & & 7 & 10 & 12 & 5 & 113. n-triacont-1-ene & 2.2 & 100 & 190 & 150 & 130 \\
\hline 83. $\bar{n}$-nonadec-1-ene & 0.6 & 25 & 50 & 45 & 20 & 114. $\bar{n}$-triacontane & 1.1 & 360 & 1200 & 1000 & 400 \\
\hline 84. $\bar{n}$-nonadecane & 2.6 & 380 & 550 & 700 & 600 & 115. $\overline{2} 4$-thylcholest-2-ene (XVIc) & & 240 & 260 & 280 & 300 \\
\hline 85. $\overline{2}$-methy Inonadecane & & 88 & 160 & 140 & 90 & 116. n-hentriacont-1-ene & 4.0 & 200 & 300 & 400 & 350 \\
\hline 86. $n-\cos -1$-ene & 0.1 & 23 & 62 & 50 & 40 & 117. $\bar{n}$-hentriacontane & 9.5 & 4000 & 7700 & 3300 & 7500 \\
\hline B7. $\bar{n}-c o s a n e$ & 2.0 & 70 & 150 & 300 & 250 & 118. $\bar{n}$-dotriacontane & 1.8 & 360 & 740 & 550 & 400 \\
\hline 88. 2-me thy l cosane & & 5 & 10 & 12 & 10 & 119. 17B(H), 21B (H)-hopane (XXVI) & 0.4 & 440 & 900 & 750 & 600 \\
\hline 89. 2,6,10,14-tetram & yl-7- & $-13-1$ & ethy & pent- & 4-eny 1 & -pentadec-2-eneb & 7.8 & 800 & 1300 & 1200 & 1500 \\
\hline 90. n-heneicosane & 4.2 & 320 & 700 & 1200 & 1400 & 120. diploptene $(x X V)$ & 0.8 & 5800 & 8500 & 7500 & 4000 \\
\hline 91. n-docos-1-one & 0.8 & 31 & 89 & 200 & 100 & 121. n-tritriacontane & 8.7 & 2000 & 3000 & 3300 & 8000 \\
\hline 92. $\bar{n}-$ docosane & 2.8 & 140 & 310 & 400 & 400 & 122. $\bar{n}$-tetratriacontane & 1.8 & 150 & 250 & 230 & 180 \\
\hline 93. $\bar{n}$-tricos-1-enet & 9.5 & 1600 & 2300 & 1700 & 1000 & 123. $\bar{n}$-pentatriacontane & 2.2 & 400 & 700 & 570 & 900 \\
\hline
\end{tabular}

a) sample description as in Table 1. b) compound present in fractions F1 and F2.

c) tentative identification.

the methylheptadecanes are specific cyanobacterial indicators (HAN et al., 1968; GELPI et al., 1970).

A significant proportion of the hydrocarbons present in Santa Olalla sediments and water particulates is related to the surrounding vegetation. The allochthonous compounds present in higher concentration constitute a distribution of $\mathrm{C}_{23}-\mathrm{C}_{35} n$-alkanes, with a maximum at $\mathrm{C}_{31}-\mathrm{C}_{33}$ and an odd carbon number preference. These distributions are indicative of contributions from higher plants (EGLINTON and HAMILTON, 1967). Concurrently with these saturated hydrocarbons, there is also a distribution of $\mathrm{C}_{23}-\mathrm{C}_{31}$ odd carbon numbered $n$-alkenes with a maximum at $\mathrm{C}_{25}$. Dimethyl disulphide derivatization showed that the unsaturation is located at the terminal position in all homologs (YRUELA et al., 1990). These $n$-alk-1-ene distributions have also been observed in other lacustrine environments (GIGER et al., 1980; CARDOSO et al., 1983; AlBAigÉs et al., 1984b; CRANWELl et al., 1987).

$\mathrm{C}_{21}-\mathrm{C}_{27}$ odd numbered $n$-alkenes have been identified in one cyanobacterium, Anacystis montana (GELPI et al., 1970) which, in the absence of observable higher plant sources, has led to an assumption of cyanobacterial origin for the occurrence of $\mathrm{C}_{19}-\mathrm{C}_{35}$ olefins in Antarctic soils (MATSUMOTO et al., 1990). However, high amounts of straight chain $n$-alkenes have been reported in plants such as sugar cane (SORM et al., 1964), roses (MLADENOVA et al., 1983), and ferns (LYTLE et al., 1976). The biosynthetic mechanism involves fatty acid decarboxylation (GORGEN and BOLAND, 1989) which is consistent with the odd to even carbon number predominance of the distributions of $n$-alkenes found in lacustrine environments.

The $\mathrm{C}_{23}-\mathrm{C}_{31} n$-alkenes present in the Santa Olalla Lagoon are concurrent with other terrigenous components such as the $\mathrm{C}_{23}-\mathrm{C}_{35} n$-alkanes, $\mathrm{C}_{20}-\mathrm{C}_{32} n$-alkanoic acids, and polycyclic higher plant markers that will be discussed later. Moreover, these $n$-alkanes exhibit a distribution that is very close to $n$-alkene mixtures found in other lacustrine environments dominated by contributions from terrestrial vegetation (ALBAIGEs et al., 1984b). Their origin is therefore likely related to terrigenous sources. The presence of these compounds both in the water column particulates and sediments is consistent with the strong similarity in the lipid composition of these two types of samples and reflects an important degree of sediment resuspension.

\section{Ketones}

The methoxy-ethers, ketones, and alcohols were collected in fractions IV, V, and VI. Representative chromatograms of these column chromatography fractions are displayed in Figs. 6 and 7. Peak identifications and concentration ranges are given in Tables 5 and 6.

The alkanone mixtures of Santa Olalla sediments are composed of $n$-heptadecan-2-one and an unimodal distribution of $\mathrm{C}_{23}-\mathrm{C}_{33} n$-alkan-2-ones with an odd over even carbon number preference maximizing at the $\mathrm{C}_{25}$ or $\mathrm{C}_{27}$ homologs (see Fig. 6-F5 and Table 5). The similarity of these 
Table 4. Hydrocarbons identified in fractions F2 and F3 of Santa Olalla sample extracts.



profiles with those of the $n$-alkanes suggests that these ketones originate from the oxidation of these hydrocarbons (ALBAIGES et al., 1984a), a process that likely occurs in the water column.

\section{Alcohols}

The acyclic alcohols consist of complex mixtures encompassing straight, branched, and isoprenoid alkan-1-ols and alkan-2-ols as well as mid-chain alcohols (see Figs. 6 and 7 , and Tables 5 and 6). Similar to the fatty acids, the fractions studied here include both the free components and the esterified alcohol mnieties.

The major classes exhibit bimodal distributions of even carbon number predominated $\mathrm{C}_{14}-\mathrm{C}_{34}$ n-alkan-1-ols. The lower mode $\left(\mathrm{C}_{14}-\mathrm{C}_{18}\right.$ range $)$ maximizes at $n$-hexadecan-1-ol, the most abundant alcohol in the lagoon, which is currently associated with algal (WEETE, 1976) or bacterial (ALBRO, $1976)$ inputs. The second mode $\left(C_{20}-C_{34}\right.$ range $)$ resembles the $n$-alkan-1-ol distributions found in higher plant waxes (EGLINTON and HAMILTON, 1967).

In addition to these alcohols, several unsaturated and methyl branched species have been identified. A definite interpretation of their significance is difficult due to the limited number of studies on alcohol compositions of organisms. From a qualitative point of view, the branched and unsaturated $n$-alkan-1-ol components parallel the fatty acid distributions described above: the same iso- and anteiso-homologs are found, and the major $n$-alkenols are unsaturated at the same $\Delta^{9}$ and $\Delta^{11}$ positions. A higher proportion of methyl branched compounds is, however, observed in the alcohol distributions. These branched methyl alcohols have been attributed to bacterial inputs (CRANWELL, 1980; DE LEEUW et al., 1985). They have been found in significant concentration in the alcohol fraction of diverse cyanobacterial mats (DE LEEUW et al., 1985). In cases where the mat organic extracts were not saponified, they have been identified in the alcohol moiety of the sedimentary wax esters (DOBSON et al., 1988).

The bacterial signature of the alcohol fraction may also be recognized by the presence of $n$-alkan-2-ols (CRANWELL, 1980). These compounds have been identified in the cell walls of bacteria such as Escherichia coli (NACCARATO et al., 1972). In this respect, the simple distribution of $n$-alkan-2-ols found in Santa Olalla sediments, encompassing only the $C_{17}, C_{18}$, and $\mathrm{C}_{20}$ homologs (see Table 6), is in correspondence with the wax composition of certain bacteria (i.e., Mycobacterium phlei; ASSELINEAU, 1966).

Other contributions are also represented by the secondary alcohols. This is the case of a complex distribution of $\mathrm{C}_{23}-$ $\mathrm{C}_{31}$ mid-chain-substituted alcohols with odd carbon number preference in the sediments. Each homolog exhibits several positional isomers, the central and even carbon number of the aliphatic chain being the preferred sites for substitution, i.e., C-14 for nonacosanols. These types of distributions have been identified in the solvent extracts of several higher plants (NetTing and MaCEY, 1971; ChibNall et al., 1931), and their occurrence in lacustrine environments is indicative of terrestrial organic matter inputs. 

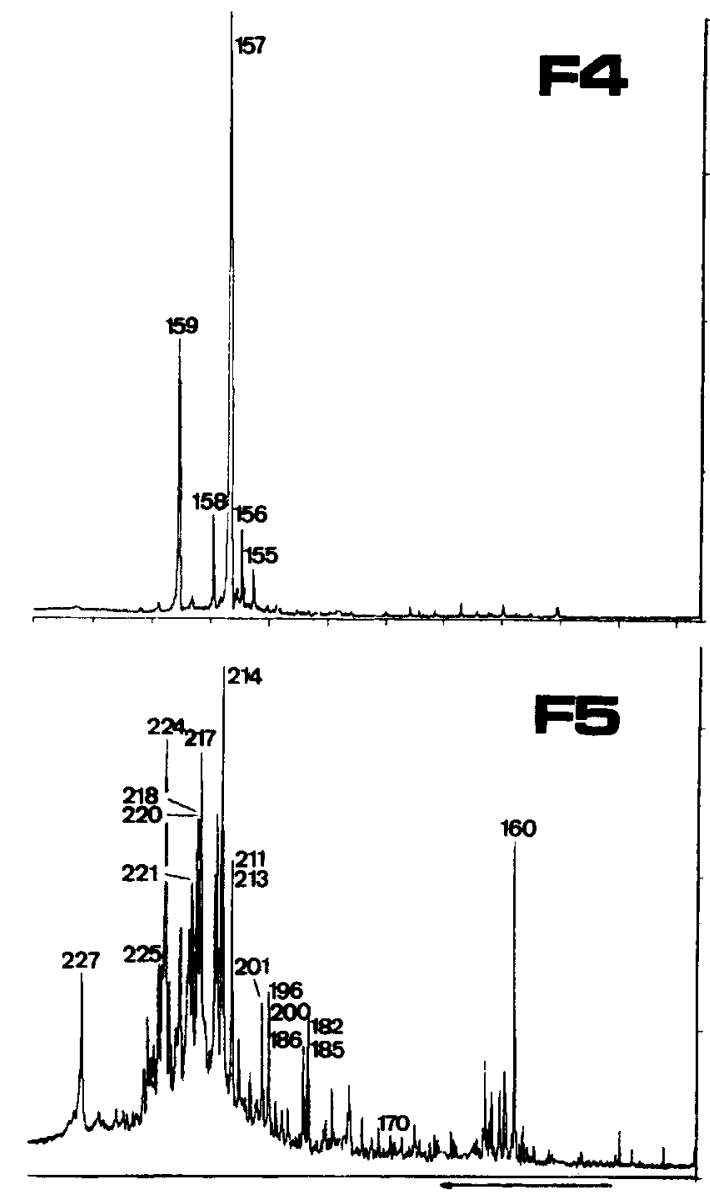

FIG. 6. Representative chromatograms of the F4 and F5 neutral oxygenated fractions of Santa Olalla sediments. Peak identifications are in Table 5.

The terrigenous contributions are therefore represented by a group of acyclic lipids that is dominated by the $\mathrm{C}_{20}-\mathrm{C}_{32}$ even carbon numbered $n$-fatty acids $(170-350 \mu \mathrm{g} / \mathrm{g})$ and also includes the distributions of $\mathrm{C}_{23}-\mathrm{C}_{35}$ odd carbon numbered $n$-alkanes $(15-40 \mu \mathrm{g} / \mathrm{g}), \mathrm{C}_{20}-\mathrm{C}_{34}$ even carbon number predominated $n$-alkan-1-ols $(20-40 \mu \mathrm{g} / \mathrm{g})$, and $\mathrm{C}_{23}-\mathrm{C}_{31}$ midchain-substituted alcohols $(0.1-0.9 \mu \mathrm{g} / \mathrm{g})$.

In addition to the secondary alcohols, several $C_{30}-C_{32} 1,13$ and 1,15 alkanediols have been identified (see compound Nos. 293, 294, 299, and 304 in Table 6). This mixture is dominated by $n$-dotriacontane-1,15-diol that is found at a similar concentration as the major sterols or some hopanols. These alkanediols have also been reported in marine sediments (DE LEEUW et al., 1981; SMITH et al., 1983; TEN HAVEN et al., 1987). Dinoflagellates and coccolithoporids were initially suggested as possible precursors (SMITH et al., 1983) but more recent studies have pointed to Eustigmatophyceae (VOLKMAN et al., 1989) or cyanobacteria (MORRIS and BRASSELL, 1988). In the Santa Olalla Lagoon, no Eustigmatophyceae algae have been found (TOJA, pers. commun.), pointing to the abundant cyanobacteria as the likely precursors.

In another highly productive lagoon, after a detailed study of potential precursor organisms, the occurrence of these compounds has also been attributed to cyanobacteria
(CRANWELl et al., 1987). However, to date these alkanediols have only been identified in field populations of one fresh/ brackish water cyanobacterium, Aphanizomenon flos aquae (MORRIS and BRASSELL, 1988), but they have not been found in the corresponding cultured species (DE LEEUW, pers. commun.). More information is therefore needed for a better source assignment. Particularly, more cyanobacterial species should be investigated; $A$. flos aquae is not included in the thirteen species of cyanobacteria identified in Santa Olalla.

\section{Isoprenoid Compounds}

Early diagenesis of chlorophylls leads to the generation of large amounts of phytol (JoHNs et al., 1966; CoX et al., 1972) which is subsequently transformed to other isoprenoid products. The phytol-related components found in Santa Olalla Lagoon are summarized in Fig. 8.

\section{Alcohols}

The concentrations of free and esterified phytol $(\sim 27 \mu \mathrm{g} /$ $\mathrm{g}$ in the sediments; $3.1 \mu \mathrm{g} / \mathrm{L}$ in the water particulates)

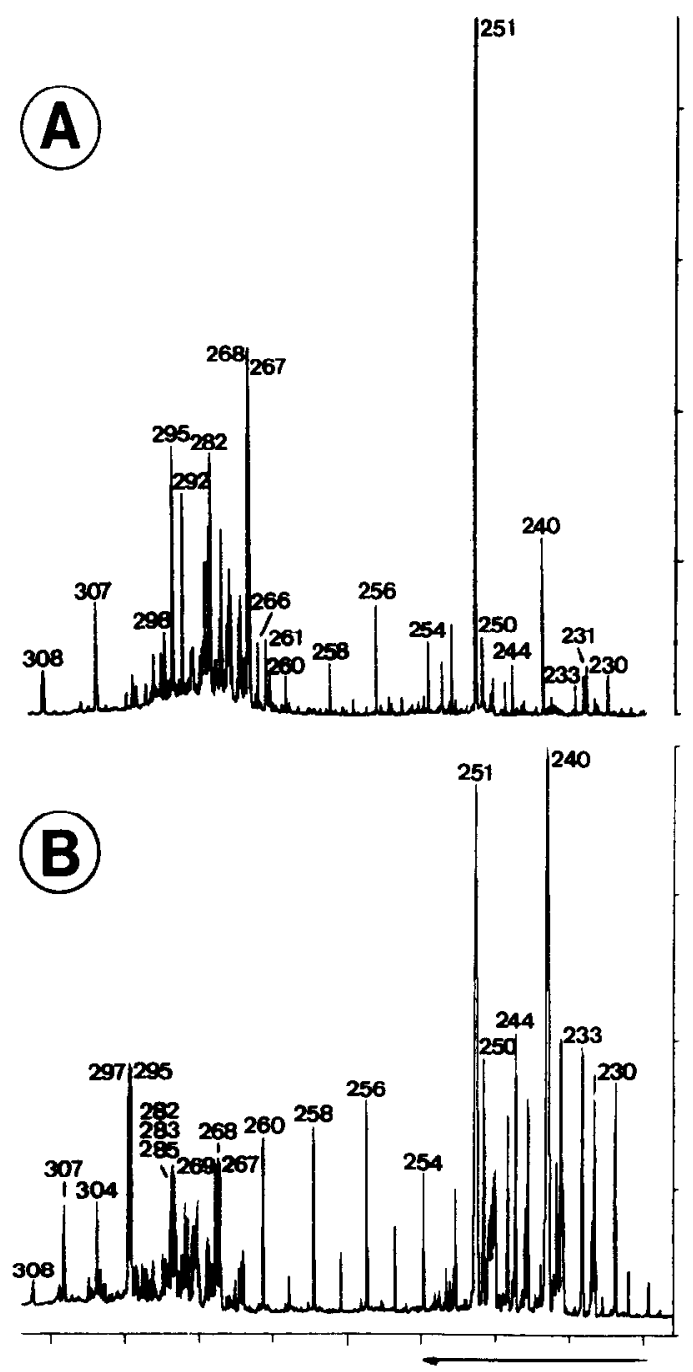

FIG. 7. Representative chromatograms of the alcohol fractions, F6, of Santa Olalla water particulates (A) and sediments (B). Peak identifications are in Table 6. 


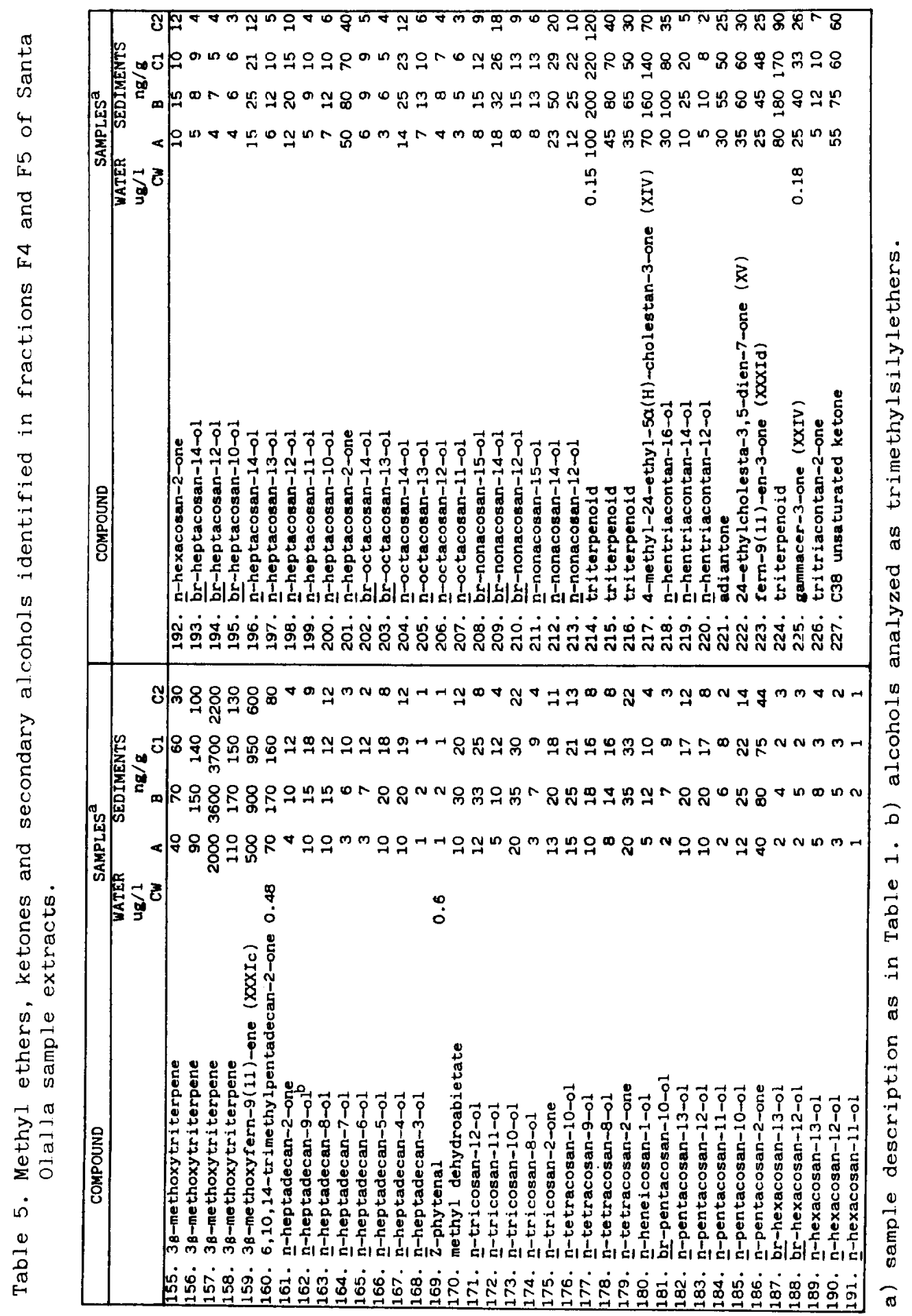









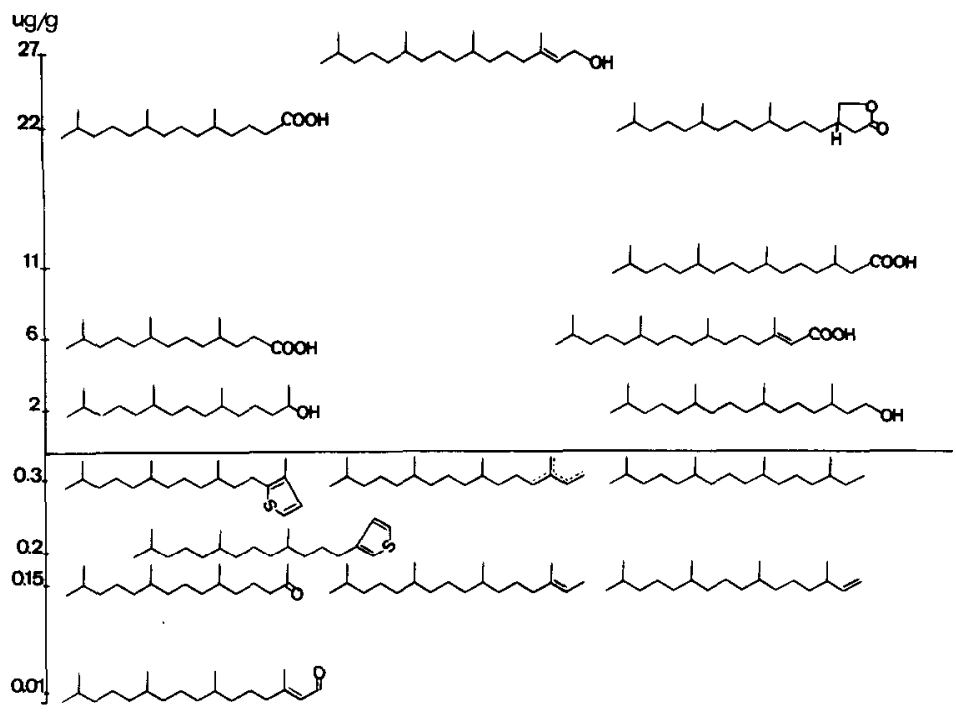

FIG. 8. Phytol-related compounds found in Santa Olalla sediments.

correspond to the second most abundant alcohol and the predominant isoprenoid compound. The presence of dihydrophytol and 6,10,14-trimethylpentadecan-2-ol is currently attributed to transformation reactions by anaerobic eubacteria (BROOKs et al., 1978), a process which likely occurs in the anoxic sediment. However, direct microbial inputs of phytol or dihydrophytol (e.g., from the decomposition of phytenyl glycerolipids; VOLKMAN et al., 1991) cannot be excluded.

\section{Fatty acids}

A series of $\mathrm{C}_{16}-\mathrm{C}_{20}$ regular isoprenoid acids dominated by the $C_{17}$ homolog is found in Santa Olalla sediments and water particulates. These acids, especially 5,9,13-trimethyltetradecanoic acid, are indicative of oxic decomposition processes (BroOKS and MAXWEI., 1974). Phytenic acid, another mild oxidation phytol product (IKAN et al., 1975), has also been identified in the lagoon. Likewise, the occurrence of these acids is characteristic of transformations in the water column and subsequent accumulation of the reaction products in the sediments. Other regular isoprenoid acids not related to phytol have also been found. This is the case of 2,6,10,14,18-pentamethylnonadecanoate which obviously originates from isoprenoid molecules larger than $\mathrm{C}_{20}$.

\section{Lactones}

Early diagenesis of phytol may also result in non-acidic products such as $\gamma$-lactones. The two $\gamma$-lactones found in Santa Olalla Lagoon correspond to the C-3 isomeric mixture of 3,7,11,15-tetramethyl-17-hexadecanolide (I). These have also been identified in Mangrove Lake, Bermuda (HATCHER et al., 1983) and in some ponds of Santa Pola solar saltern (BARBE et al., 1990). Very few reports exist on the occurrence of lactones in recent sedimentary samples. Hydroxyacids and diols are the presumed phytanic $\gamma$-lactone precursors (DIDYK et al., 1978), pointing to the same type of phytol transformations as those leading to the formation of isoprenoid acids. As illustrated in Fig. 8 both 5,9,13-trimethyltetradecanoic acid and 3,7,11,15-tetramethyl-17-hexadecanolide (I) are major isoprenoid products in Santa Olalla samples, which suggests a formation mechanism related with water column oxidation processes. In this respect, both Santa Olalla Lagoon and Santa Pola ponds (BARBE et al., 1990) exhibit shallow water columns overlying anoxic sediments. Perhaps these phytanic lactones are formed in the water column due to relatively high oxidation conditions and are protected from further transformation in the reducing environment of the bottom sediments.

\section{Ketones and aldehydes}

6,10,14-trimethylpentadecan-2-one and Z-phytenal have been identified, but in very minute amounts. These compounds are early oxidation products of phytol, being considered as possible intermediates in the formation of 5,9,13trimethyltetradecanoic acid and phytenic acid, respectively (IKAN et al., 1973; RONTANI et al., 1990).

\section{Hydrocarbons}

Several $\mathrm{C}_{20}$ isoprenoid hydrocarbons (phytane and various phytenes) have been found in a concentration range of two orders of magnitude lower than the oxigenated derivatives (see Table 2 and Fig. 4). These hydrocarbons may originate from phytol degradation (DIDYK et al., 1978), or from direct contributions from methanogenic bacteria (TORNABENE et al., 1979).

Other isoprenoid hydrocarbons, not related to phytol, are also found in Santa Olalla samples. Among these, squalene (II) is the component present in higher concentrations in sediments (2.0-3.8 $\mu \mathrm{g} / \mathrm{g}$, see Fig. 5 and Table 4). Squalene (II) is a major hydrocarbon in diverse cyanobacterial mats (BOON et al., 1983). Its occurrence is associated with bacteria, fungi, and yeasts (BIRD and LYNCH, 1974). Some methanotrophic bacteria, i.e., Methylococcus sp, contain up to 0.5 dry wt\% squalene (BIRD et al., 1971). Squalene (II) and other $C_{30}$ isoprenoid hydrocarbons also constitute the major neutral 
lipids of archaebacteria (TORNABENE et al., 1979). In Santa Olalla sediments, the relative composition of squalene (II), di- and tetrahydrosqualenes and $\mathrm{C}_{20}$ isoprenoid hydrocarbons parallels the composition of a Methanobacterium species reported by TORNABENE et al. (1979). The presence of methanogenic bacteria in alkaline lakes such as Wadi Natrum (Egypt) has recently been demonstrated (TINDALL, 1988).

A group of $\mathrm{C}_{25}$ highly branched isoprenoid hydrocarbons (III) is also found in the Santa Olalla Lagoon. It is represented by two olefins, one exhibiting a diunsaturated structure and occurring in relatively high concentrations $(0.8-1.3 \mu \mathrm{g} / \mathrm{g}$, see Figs. 4 and 5), and the other being triunsaturated and minor. Using the epoxide derivatization technique, we have tentatively identified the former component as 2,6,10,14-tetramethyl-7-(3-methylpent-4-enyl)pentadec-2-ene (YRUELA et al., 1990). Highly branched isoprenoid hydrocarbons have been found in several lagoons and coastal areas (ROBSON and ROWLAND, 1986; ALBAIGÉs et al., 1984a,b; REQUEJO et al., 1984). A macroscopic seaweed Enteromorpha prolifera (ROWLAND et al., 1985) and diatoms (NicHOLs et al., 1988) have been reported to contain these compounds. However, the widespread occurrence of these highly branched isoprenoid hydrocarbons in aquatic environments and the small contributions of these organisms in Santa Olalla Lagoon suggest that other biogenic precursors have still to be identified.

\section{Sulphur compounds}

During the very early stages of diagenesis, the incorporation of sulphur into the isoprenoid chain is possible (BRASSELL et al., 1986). Two organic sulphur compounds of this type have been found in Santa Olalla sediments, 3-methyl-2(3,7,11-trimethyldodecyl)thiophene (IV) and 3-(4,8,12-trimethyltridecyl)thiophene (V). These, in turn, are the major thiophenes found in other sedimentary basins, and their isomeric distribution is consistent with the composition found in nonhypersaline basins (BRASSELL et al., 1986; RULLKOTTER et al., 1988). No isoprenoid thiolanes have been found, which is also consistent with the results observed in other recent lacustrine environments (BARBE et al., 1990). The presence of these thiophenes witnesses the activity of sulphate-reducing bacteria in the anoxic sediments.

\section{Phytanyl-glycerol ethers}

Ether-linked glycerolipids are generally representative of archaebacteria (LANGWORTHY et al., 1982). A detailed characterization of the sedimentary glycerol ethers is beyond the scope of the present study, but some relatively low molecular weight species are amenable to $\mathrm{GC}$ analysis by trimethylsilyl derivatization. In this respect, notable amounts of di-O-phytanyl glycerol (VI) have been found in Santa Olalla sediments $(0.8-3.7 \mu \mathrm{g} / \mathrm{g})$ and water particulates $(0.17 \mu \mathrm{g} / \mathrm{L})$. This compound is characteristic of halophilic (KATES, 1978; KUSHWAHA et al., 1982) and methanogenic (TORNABENE and LANGWORTHY, 1978; TORNABENE et al., 1978) archaebacteria. The occurrence of halophiles in Santa Olalla Lagoon is unlikely because of insufficient water salinity $(0.6 \%$ whereas at least $5-10 \%$ are required; KATES, 1978), so that the occurrence of di-O-phytanyl glycerol in this lagoon can be at- tributed to the activity of methanogens. In fact, quantitation of di-O-phytanyl glycerol has been proposed as a method for biomass measurement of methane-forming bacteria in environmental systems where the presence of halophiles can be excluded (MARTZ et al., 1983).

\section{Chromans}

2,5,7,8-Tetramethyl-2-(4,8,12-trimethyltridecyl)-chroman (VII) has been found in the sediments of Santa Olalla Lagoon at low concentrations. This compound has been tentatively identified by comparison with reference mass spectral data (SINNINGHE DAMSTE et al., 1987). Although the components of the chroman series seem to be structurally related to tocopherols, no diagenetic link has yet been established between both types of molecules, nor is a biogenic source known for their occurrence in the geosphere.

\section{Steroids}

The steroid composition of Santa Olalla samples is described in Tables 3, 5, and 6, and Figs. 4, 5, and 7. Sterols are the major constituents of this lipid group $(2.9 \mu \mathrm{g} / \mathrm{L}$ and $65 \mu \mathrm{g} / \mathrm{g}$ in the water particulates and sediments, respectively); unsaturated steroid hydrocarbons $(0.8 \mu \mathrm{g} / \mathrm{L}$ and $3.1 \mu \mathrm{g} / \mathrm{g}$ in water particulates and sediments, respectively) and steroid ketones $(0.2 \mu \mathrm{g} / \mathrm{g}$ in sediments) are also present.

\section{Sterols}

Representative chromatograms of the alcohol fraction in sediments and water particulates are shown in Fig. 7. Although cholest-5-en-3 $\beta$-ol (VIIIa) and cholestan-3 $\beta$-ol (IXa) predominate, 24-ethylcholest-5-en-3 $\beta$-ol (VIIIc) and 24ethylcholestan-3 $\beta$-ol (IXc) are usually found in similar concentrations. The 24-methyl sterols are relatively depleted.

According to the sterol compositions indicated in Table 6 , the average 24-methylcholest-5-en-3 $\beta$-ol (VIIIb):24-ethylcholesta-5,22-dien-3 $\beta$-ol (Xc):24-ethylcholest-5-en-3 $\beta$-ol (VIIIc) ratios for the water particulates and sediments are 1: 2.3:3.0 and 1:3:5, respectively. In marine environment studies, these values have been observed to be indicative of higher plant origins (VOLKMAN, 1986). However, this criterion of evaluation cannot be directly extrapolated to the Santa Olalla Lagoon because the sterol composition of some cyanobacteria is characterized by a relative high proportion of 24-ethyl sterols (NES and MCKEAN, 1977; NISHIMURA and KOYAMA, 1977), providing ratios between 1:1.3:1.3 and 1:26:60 (PAOLETT et al., 1976; KOHLHASE and POHL, 1988). In particular, the composition of Spirulina platensis, the most abundant cyanobacterium identified in the lagoon exhibit a ratio of 1:7:51 (PAOLETTI et al., 1976). The predominant $C_{29}$ homolog of Spirulina platensis is 24(S)-ethylcholest-5-en-3 $\beta$-ol (clionasterol) (PAOLETTI et al., 1976), whereas $\beta$-sitosterol, the characteristic higher plant sterol, is the corresponding $24 \mathrm{R}$ isomer. Nevertheless, the elucidation of the sterol $\mathrm{C}-24$ stereochemistry has not been attempted in the present study. The occurrence of 24-ethylsterols in cyanobacterial mats has been attributed to cyanobacteria or diatoms (EDMUNDS and EGLINTON, 1984). 
In addition to these major sterols, several $4 \alpha$-methyl sterols have also been identified (compounds Nos. 287, 288, and 290 in Table 6). $4 \alpha$-methyl sterols are generally considered to represent contributions from dinoflagellates (BOON et al.,

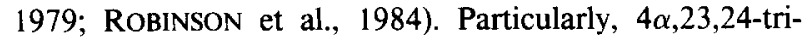
methyl-5 $\alpha(\mathrm{H})$-cholest-22(E)-en-3 $\beta$-ol (dinosterol, $\mathrm{XI}$ ) is widely accepted as a specific dinoflagellate marker. In some cases, this species has been considered as a very unlikcly prccursor (EDMUNDS and EGLINTON, 1984; NiCHOLS et al., 1990), but an alternative algal source for dinosterol still remains to be positively identified. In fact, the presence of this sterol in the Santa Olalla Lagoon can reflect dinoflagellate inputs. As illustrated in Fig. 2, primary producers other than cyanobacteria are found in significant amounts during short periods. However, several $4 \alpha$-methyl-24-cthyl stenols and stanols have recently been identified in cyanobacteria (KOHLHASE and POHL, 1988) and prymnesiophyte algae of the genus Pavlova (VOLKMAN et al., 1990). This suggests that the occurrence of $4 \alpha$-methyl-24-ethyl-5 $\alpha$ (H)-cholest-22(E)en-3 $\beta$-ol (XII) and $4 \alpha$-methyl-24-ethyl-5 $\alpha(\mathrm{H})$-cholestan-3 $\beta$ ol (XIII) in the lagoon may also reflect cyanobacterial inputs.

Another distinct feature of the sedimentary sterol distributions of the Santa Olalla Lagoon is the large proportion of stanols. These may originate from direct biogenic inputs (NiShIMURA and KOYAMA, 1977; VolKMAN et al., 1981), including cyanobacteria (KOHLHASE and POHL, 1988), or from in situ hydrogenation processes (GASKELL and EGLINTON, 1975; NISHIMURA, 1977). The strong similarity between the sedimentary distributions of $\Delta^{5}$-sterols and $5 \alpha(\mathrm{H})$-stanols (also observed for the $\Delta^{22}$ compounds) and the presence of $5 \beta(\mathrm{H})$-stanols in significant proportions are indicative of the hydrogenation processes. This conversion is generally accepted to occur via $\Delta^{4}$ sten-3-ones (EDMUNDS et al., 1980; ROBINSON et al., 1984). However, very few stanones, and no $\Delta^{4}$ sten-3-ones, have been found in the sediments of the Santa Olalla Lagoon. The role of stanones as intermediates seems to be affected by the redox potential of the sedimentary system. In highly reducing environments the transformation has been observed to occur by direct conversion (MERMOUD et al., 1984). The Santa Olalla Lagoon sediments are likely one of these environments. Further details on the significance of the distributions of stanols in this lagoon are given elsewhere (GRIMALT et al., 1990).

\section{Steroidal ketones}

Steroidal ketones have been found as minor sedimentary constituents. Among them, $4 \alpha$-methyl-24-ethyl-5 $\alpha$ (H)-cholestan-3-one (XIV) and 24-ethylcholesta-3,5-dien-7-one $(X V c)$ have been identified. These compounds are likely oxidation products of $4 \alpha$-methyl-24-ethyl-5 $\alpha(\mathrm{H})$-cholestan-3 $\beta$ ol (XIII) and 24-ethylcholest-5-en-3 $\beta$-ol (VIIIc), respectively. The formation of cholesta-3,5-dien-7-ones (XV) is considered to be mediated via hydroperoxides that are subsequently dehydrated at C-3 (VAN LIER and SMITH, 1970; HOLLAND and DIAKOW, 1979). The presence of these steroid ketones is consistent with the above described occurrence of 6,10,14-trimethylpentadecan-2-one and probably represents an additional example of the water column oxidation processes.

\section{Unsaturated steroid hydrocarbons}

Sterenes $(0.6-1.3 \mathrm{ng} / \mathrm{g})$ and steradienes $(1.3-2.1 \mathrm{ng} / \mathrm{g})$ constitute the predominant steroid hydrocarbons in the sediments of the Santa Olalla Lagoon. Steratrienes $(0.43-0.74 \mathrm{ng} / \mathrm{g}$ ) and steratetraenes $(0.025-0.060 \mathrm{ng} / \mathrm{g})$ are found in minor proportion. The sterene series is represented by a distribution of $\mathrm{C}_{27}-\mathrm{C}_{29}$ ster-2-enes (XVI) maximized at $\mathrm{C}_{27}$. The steradiene distribution consists of stera-3,5-dienes (XVII; the predominant components), stera-N,22-dienes (XVIII), and stera5,24(28)-dienes (XIX), respectively, maximizing at their $\mathrm{C}_{27}$, $\mathrm{C}_{29}$, and $\mathrm{C}_{28}$ homologues.

The occurrence of sterenes in recent sediments is currently attributed to sterol dehydration (DASTILLUNG and ALBRECHT, 1977). Accordingly, there is a direct correspondence between ster-2-enes (XVI) and stanols (IX) and between stera3,5-dienes (XVII) and $\Delta^{5}$-stenols (VIII). The steratrienes may also be formed from $\Delta^{5}$-stenols via steroid diol intermediates. The stera-N,22-dienes (XVIII) are possibly related to $\Delta^{22}$ stanols. They may also originate from dehydration of $\Delta^{5.22}$. stenols (XI) to $\Delta^{3,5,22}$-steratrienes, hydrogenation to $\Delta^{5,22}$ steradienes, and subsequent isomerization (DE LEEUW et al., 1989). Some of these processes may be microbially mediated (WAKEHAM, 1987).

\section{Hopanoids and Gammaceroids}

Tetrahymanol (XX; average concentration $14 \mu \mathrm{g} / \mathrm{g}$ ), $17 \beta$ (H),21 $\beta(\mathrm{H})$-hopan-22-ol (XXI; $13 \mu \mathrm{g} / \mathrm{g})$, and $17 \beta-(\mathrm{H}), 21 \beta$ (H)-bishomohopanol $(\mathrm{XXIIb} ; 11 \mu \mathrm{g} / \mathrm{g})$ constitute the predominant polycyclic molecules in Santa Olalla sediments which also contain high concentrations of $17 \beta(\mathrm{H}), 21 \beta(\mathrm{H})-$ bishomohopanoic acid (XXIII; $9 \mu \mathrm{g} / \mathrm{g}$ ). In the water particulates, $17 \beta(\mathrm{H}), 21 \beta(\mathrm{H})$-bishomohopanoic acid (XXIII) and tetrahymanol $(\mathrm{XX})$ are the predominant polycylic species, 4.6 and $1.1 \mu \mathrm{g} / \mathrm{L}$, respectively. $17 \beta(\mathrm{H}), 21 \beta(\mathrm{H})$-bishomohopanol (XXIIb) is also present in significant concentration in the water particulates $(0.36 \mu \mathrm{g} / \mathrm{L})$, but no $17 \beta(\mathrm{H}), 21 \beta(\mathrm{H})-$ hopan-22-ol (XXI) has been detected in this lagoon compartment.

The widespread occurrence of tetrahymanol (XX) in coastal marine sediments has recently been reported (VENKATESAN, 1989; TEN HAVEN et al., 1989; VENKATESAN et al., 1990). This compound has also been observed in algal or microbial mats from hypersaline systems (VENKATESAN, 1989; BarbF et al., 1990), and its occurrence in the Santa Olalla Lagoon expands further the diversity of environments where gammacerol is present. Ferns (ZANDER et al., 1969), the rumen fungus Piromonas communis (KEMP et al., 1984), the phototrophic bacterium Rhodopseudomonas palustris (KLEEMANN et al., 1990), and the protozoan Tetrahymena pyriformis (CONNER et al., 1968) constitute the known biogenic tetrahymanol $(\mathrm{XX})$ precursors. The protozoans distributed in the mud layer that overlies Santa Olalla sediments usually range between 50 and $100 \mathrm{ind} / \mathrm{mL}$, and occasionally they reach up to several thousand ind $/ \mathrm{mL}$. The more abundant species is Platynematum socials and corresponds to the same family (Frontoniidae) as $T$. pyriformis. Other frequent protozoans in the lagoon, Frontonia marina and Uronema aff. marinus, are also from the Frontoniidae family (PEREZ 
CABrera and TOJA, 1989). T. pyriformis has not been identified but its presence is not excluded. However, as indicated in other studies (VENKATESAN, 1989; TEN HAVEN et al., 1989), the presence of tetrahymanol (XX) in the lagoon perhaps corresponds to contributions from other organisms that still remain to be identified. The recent identification of this compound in a prokaryotic organism (KLEEMANN et al., 1990) gives a further ground to this hypothesis.

Tetrahymanol (XX) has been found to be concurrent with gammacer-2-ene and gammacerane in sediment samples from ancient lacustrine environments (TEN HAVEN et al., 1989), pointing to a strong precursor/product relationship. However, neither gammacerane nor gammacer-2-ene have been identified in the Santa Olalla Lagoon. The absence of this unsaturated compound is particularly significant because dehydration seems to occur in the case of other polycyclic molecules such as the sterols, a difference that suggests a higher stability of gammacerols compared to sterols with respect to dehydration. Conversely, oxidation may be a more likely tetrahymanol transformation process. Based on a very good correspondence with the mass spectrum reported by TEN HAVEN et al. (1989), we have tentatively identified gammacer3-one (XXIV) both in the sediments and water particulates. In a similar way as for the above described steroid ketones and 6,10,14-trimethylpentadecan-2-one, this gammacerone represents an oxidation product that is likely produced in the oxic water column.

$17 \beta(\mathrm{H}), 21 \beta(\mathrm{H})$-hopan-22-ol (diplopterol) (XXI), the second major polycyclic compound in Santa Olalla sediments, is an abundant product in many bacteria (ROHMER et al., 1984), although it can also be related with Tetrahymena inputs (CONNER et al., 1968). This compound is absent in the lagoon waters which may reflect a low stability in oxic or suboxic conditions. In this respect, both the sediments and water particulates exhibit an important concentration of diploptene (XXV) which may represent a diplopterol dehydration product (VENKATESAN, 1988, 1989).

The presence of diploptene $(\mathrm{XXV})$ in the lagoon may also correspond to direct biogenic inputs. This compound is an abundant constituent of cyanobacteria (GELPI et al., 1970) and other prokaryotes (DE ROSA et al., 1971; OURISSON et al., 1979). Other hopanoid hydrocarbons present at lower concentrations: $17 \beta(\mathrm{H}), 21 \beta(\mathrm{H})$-hopane (XXVI), 22,29,30trisnor-hop-17(21)-ene (XXVIIa), hop-17(21)-ene (XXVIb), and an hopene (No. 143 in Table 4) exhibiting a mass spectrum similar to that of diploptene but eluting at shorter retention time (DASTILUNG, 1976; FARRAN et al., 1987), may also be indicative of direct inputs from prokaryotic organisms (HowARD et al., 1984), including cyanobacteria (BOUDOU et al., 1986). Some of them, namely the hop-17(21)-enes, may also be early transformation products of diploptene (ENSMINGER, 1977).

$17 \beta(\mathrm{H}), 21 \beta(\mathrm{H})$-bishomohopanol (XXIIb) and the other hopanoid alcohols (Table 6) may also originate from prokaryotic organisms (FORSTER et al., 1973; OURISSON et al., 1979), including cyanobacteria (ROHMER and OURISSON, 1976). 17 $\beta(\mathrm{H}), 21 \beta(\mathrm{H})$-bishomohopanoic acid (XXIII) and the other hopanoic acids (Table 2) are likely transformation products of the extended polyhydroxyhopanes. The predominance of carboxy- and hydroxy-hopanoids in the water par- ticulates and sediments, respectively, is in correspondence with the redox conditions prevailing in these two lagoon compartments and is also consistent with the trends observed in other sedimentary areas between the distributions of hopanoid compounds and the oxic/reducing conditions of the depositional environment (GRIMALT and ALBAIGES, 1990). The decomposition of polyhydroxyhopanes may also give rise to hopanoid components with other functionalities such as hopanones [e.g., adiantone (XXVIII)] in a similar way as the processes leading to the formation of gammacer-3-one, steroid ketones, and the $C_{18}$ isoprenoid ketone.

\section{Other Triterpenoids}

In addition to the hopanoids and gammaceroids, $\alpha$ - and $\beta$-amyrin (XXIX and XXX, respectively) have been identified. These ursane and oleanane compounds are common constituents of higher plants (CHANDLER and HOOPER, 1979; PANT and RASTOGI, 1979; DAS and MAHATO, 1983). In some cases, the same triterpenoid structure exhibits various oxygenated derivatives, namely oxo-, hydroxy-, and $3 \beta$-methoxycomponents. This is illustrated in Fig. 9 (peaks Nos. 159, 280 , and 223) where the mass spectra corresponding to fern-9(11)-en-3 $\beta$-ol (XXXIb), $3 \beta$-methoxyfern-9(11)-ene (XXXIc), and fern-9(11)-enone (XXXId) are shown. Their A-C ring moieties are represented by the $m / z 273$ (XXXIb), 331 (XXXIc), and 257 (XXXId) mass fragments that, similarly to the molecular weight ions, reflect the functional group present in each structure. These compounds have been tentatively identified by comparison with reference mass spectra and retention time data (BRYCE et al., 1967b; NISHIMOTO et al., 1968).

$3 \beta$-Methoxyfern-9(11)ene (XXXIc) has been identified in Graminae (BRYCE et al., 1967a,b; NISHIMOTO et al., 1968). In fact, this compound was initially referred to as arundoin because it was found in a grass designated as Arundo conspicua (later identified as Cortaderia toetoe). In this first characterization an oleanoid structure was attributed to the compound (EGLINTON et al., 1964), but later the fernene ring system was established (E:C friedo-isohop-9(11)-ene; BRYCE et al., 1967a). Its occurrence in the Santa Olalla Lagoon may be representative of the surrounding gramineous vegetation (Agrostis sp).

Another isomer, fern-7-en-3 $\beta$-ol (XXXIIb), and the corresponding hydrocarbon, fern-7-ene (XXXIIa), have also been identified. Their occurrence may also be related to the vegetation surrounding the lagoon. However, fernenes have also been identified in microorganisms (HowARD et al., 1984) and have been found in sedimentary environments devoid of higher plant inputs (VOLKMAN et al., 1986). In some cases, their occurrence has been attributed to microbial sources (BRASSELl et al., 1980).

Other oxo-, hydroxy-, and methoxy-triterpenoid components have also been found but not yet fully identified. One set of representative mass spectra is displayed in Fig. 9 (peaks Nos. 157, 270, and 214) which illustrates the occurrence of these functional groups in the same triterpenoid structure. A strong $\mathrm{m} / \mathrm{z} 206$ mass fragment is characteristic of the polycyclic ring system. The occurrence of $3 \beta$-methoxytriterpenoids has rarely been reported in sedimentary environments. 




\section{Aromatic Hydrocarbons}

Several polycyclic molecules resulting from the partial aromatization of diterpenoid and triterpenoid compounds have been identified (see Table 4). Thus, 17-norsimonellite (XXXIII) is a dehydrogenation product of abietane-type diterpenoids (SIMONEIT and MAZUREK, 1982). 3,4,7,12a(XXXIVa) and 3,3,7,12a-(XXXIVb) tetramethyl-1,2,3,4,4a,11,12,12a-octahydrochrysene and 3,3,7-trimethyl-1,2,3,4tetrahydrochrysene (XXXV) originate from higher plant pentacyclic tritcrpenoids, i.c., amyrins, friedelin, etc. This aromatization process involves the loss of the oxygenated Aring and subsequent progressive aromatization from ring $B$ to D (LAFLAMME and HITES, 1979; WAKEHAM et al., 1980). Trimethylchrysenes, the end products of these transformation pathways, are also present. These processes may be microbially mediated (TRENDELL et al., 1989; WolfF et al., 1989). In any case, from a quantitative point of view, these aromatic hydrocarbons represent only minor contributions to the sedimentary record of the lagoon.

\section{CONCLUSIONS}

High amounts of lipids have accumulated in the sediments of the Santa Olalla Lagoon (0.12-0.25\%). These are mainly composed of fatty acids (79-84\%) in a proportion approaching that of algae. These bulk characteristics are concomitant with the hypereutrophic conditions of this lacustrine system, but the qualitative composition of the fatty acids as well as that of the acyclic alcohols indicate that intense microbial reworking has taken place at the first stages of sedimentation. Thus, eubacterial lipids (e.g., $n$-octadec- 11 -enoic acid, isoand anteiso-pentadecanoic acids) are predominant, and the abundance of di-O-phytanyl glycerol and tetrahydrosqualenes also indicates an important activity of methanogens. The presence of trans $n$-alkenoic acids may be indicative of contributions from methane-utilizing bacteria. This microbial signature is observed both in the sediment and water column, being particularly well defined in sedimentary samples.

In this way, the cyanobacterial lipid record is obscured. Hopanoids, $\mathrm{C}_{27} / \mathrm{C}_{29}$ sterols, $n$-heptadecane, and $\mathrm{C}_{30}-\mathrm{C}_{32} 1,13$ and 1,15 diols are the main lipid contributions of the abundantly present organisms in the water column $\left(10^{6}-10^{7}\right.$ cells/ $\mathrm{mL})$ to the underlying sediments. Unfortunately, most of these compounds are common constituents of prokariots and algae, so that their usefulness for the evaluation of the significance of cyanobacterial inputs to the lacustrine system is limited. Only the distribution of $n$-alkanediols may be specifically assigned to cyanobacterial sources. Other specific markers such as the methylheptadecanes are found only in minute amounts $(0.5-0.8 \mu \mathrm{g} / \mathrm{g})$.

Higher plant wax components are also well represented. Distributions of $\mathrm{C}_{20}-\mathrm{C}_{32}$ even carbon numbered $n$-alkanoic acids, long chain ( $>\mathrm{C} 22$ ) odd carbon number $n$-alkanes and $n$-alk-1-enes, $\mathrm{C}_{23}-\mathrm{C}_{25}$ even carbon number predominated $n$-alkan-1-ols, and $\mathrm{C}_{23}-\mathrm{C}_{31}$ mid-chain-substituted alcohols are easily recognized. More specific compounds corresponding to the vegetation surrounding the lagoon, namely oxo-, hydroxy-, and methoxy-triterpenes, are also encountered. Some of them are found with the same functional groups as in the source vegetation, e.g., $3 \beta$-methoxy triterpenes, indicating a good degree of preservation of the terrigenous lipids, which contrasts with the strong microbial reworking of the cyanobacterial components.

In addition to these lipids, there is a group of major compounds in the samples analyzed, namely the $C_{25}$ highly branched isoprenoid alkenes and tetrahymanol, whose significance is unclear. The organisms previously reported for their occurrence in other environments are very minor or absent in the lagoon, which suggests that they may correspond to other biogenic precursors.

Besides bacterial reworking, the main diagenetic processes observed in the lagoon involve hydrogenation, dehydration, and oxidation. The former is essentially reflected in the transformation of $\Delta^{5}$ sterols to $5 \alpha(\mathrm{H})$ - and $5 \beta(\mathrm{H})$-stanols. The second gives rise to the transformation of sterols into sterenes and, possibly, $17 \beta(\mathrm{H}), 21 \beta(\mathrm{H})$-hopan-22-ol into diploptene. Oxidation is essentially occurring in the water column and involves the formation of 5,9,13-trimethyltetradecanoic acid, 3,7,11,15-tetramethyl-17-hexadecanolides, $Z$-phytenal and 6,10,14-trimethylpentadecan-2-one from phytol, the partial transformation of sterols into steroid ketones, and, probably, tetrahymanol into gammacer-3-one. The abundance of adiantone and bishomohopanoic acid in the water particulates can be attributed to the oxidation of extended polyhydroxyhopanes or the $\mathrm{C}_{30}-\mathrm{C}_{33}$ hydroxyhopanes found in the lagoon.

Acknowledgments-Financial support from the Spanish Ministry of Education and Science under contract No. PGC PB87-0428 is acknowledged. One of us (I.Y.) thanks a Ph.D. fellowship from F.I.S.S.

Editorial handling: J. T. Senftle

\section{REFERENCES}

ABD-EL-MALEK Y. and RizK S. G. (1963a) Bacterial sulphate reduction and the development of alkalinity. I. Experiments with synthetic media. J. Appl. Bacteriol. 26, 7-13.

ABD-EL-MALEK Y. and RizK S. G. (1963b) Bacterial sulphate reduction and the development of alkalinity II. Laboratory experiments with soils. J. Appl. Bacteriol. 26, 14-19.

ABD-EL-MALEK Y. and RizK S. G. (1963c) Bacterial sulphate reduction and the development of alkalinity. III. Experiments under natural conditions in the Wadi Natrum. J. Appl. Bacteriol. 26, 20 30.

Albaigés J., Algaba J., and Grimalt J. (1984a) Extractable and bound neutral lipids in some lacustrine sediments. Org. Geochem. 6, 223-236.

AlbaigÉs J., Grimalt J., Bayona J. M., Risebrough R., DE LAPPE B., and WALKER W. W., II (1984b) Dissolved, particulate and sedimentary hydrocarbons in a deltaic environment. Org. Geochem. 6, 237-248.

ALBRo P. W. (1976) Bacterial waxes. In Chemistry and Biochemistry of Natural Waxes (ed. P. E. KolatTUKUDY), pp. 419-450. Elsevier.

APHA (1980) Standard Methods for Examination of Water and Wastewater, 15th ed. Amer. Publ. Health Assoc., Washington, DC.

ASSELineau J. (1966) The Bacterial Lipids. Holden-Day.

BALLIO A. and BARCELLONA S. (1971) Identification of 10-methyl branched fatty acids in Microbispora parva by combined gas chromatography-mass spectrometry. Gazz. Chim. Ital. 101, 635-636.

Barbe A., Grimalt J. O., Pueyo J. J., and Albaigés J. (1990) Characterization of model evaporitic environments through the study of lipid components. Org. Geochem. 16, 815-828. 
Barnes M. A. and Barnes W. C. (1978) Organic compounds in lake sediments, In Lakes: Chemistry, Geology, Physics. (ed. A. LERMAN), pp. 127-152. Springer-Verlag.

BIRD C. W. and LYNCH J. M. (1974) Formation of hydrocarbons by microorganisms. Chem. Soc. Rev. 3, 309-328.

BiRd C. W., LYNCH J. M., PIRT S. J., REID W. W., BROOKS C. J. W., and MidDLEDITCH B. S. (1971) Steroids and squalene in Methylococcus capsulatus grown on methane. Nature 230, 473474.

Boon J. J., Rijpstra W. I. C., de Lange F., de Leeuw J. W., Yoshioka M., and SHimizu Y. (1979) The Black Sea sterols. A molecular fossil for dinoflagellate blooms. Nature 277, 125-127.

Boon J. J., Hines H., Burlingame A. L., Klok J., RiJPStra W. I. C., DE LeEuW J. W., Edmunds K. E., and Eglinton G. (1983) Organic geochemical studies of Solar Lake laminated cyanobacterial mats. In Advances in Organic Geochemistry 1983 (eds. M. BJøROY et al.), pp. 207-227. J. Wiley.

Boudou J. P., TRICHET J., RoBinson N., and BRASSELl S. C. (1986) Profile of aliphatic hydrocarbons in a recent Polynesian microbial mat. Intl. J. Environ. Anal. Chem. 26, 137-155.

Brassell S. C., Cornet P. A., Eglinton G., IsaAcson P. J., MCEVoY J., MAXWEll J. R., THOMSON I. D., TIBBETTS P. J. C., and VOLKMAN J. K. (1980) The origin and fate of lipids in the Japan Trench. In Advances in Organic Geochemistry 1979 (eds. A. G. Douglas and J. R. MaxWELL), pp. 375-392. Pergamon.

Brassell S. C., Lewis S. C., De Leeuw J. W., De Lange F., and SinNingHe DAMSTE J. S. (1986) Isoprenoid thiophenes: Novel products of sediment diagenesis? Nature 320, 160-162.

BROOKS P. W. and MAXWELl J. R. (1974) Early stage of phytol in a recently deposited lacustrine sediment. In Advances in Organic Geochemistry 1973 (eds. B. TISSOT and F. BIENNER), pp. 977991. Editions Technip.

Brooks P. W., MAXWell J. R., and Patience R. L. (1978) Stereochemical relationships between phytol and phytanic acid, dihydrophytol and $\mathrm{C}_{18}$ ketone in recent sediments. Geochim. Cosmochim. Acta 42, 1175-1180.

BRyCE T. A., Eglinton G., Hamilton R. J., Martin-SMith M., and Surramanian G. (1967a) Triterpenoids from New Zealand plants. II. The triterpene methyl ethers of Cortaderia toetoe Zotov. Phytochem. 6, 727-733.

Bryce T. A., MArtin-Smith M., OssKe G., Schreiber K., and SUBRAMANIAN G. (1967b) Sterols and triterpenoids. XI. Isolation of arundoin and sawamilletin from cuban sugar cane wax. Tetrahedron 23, 1283-1296.

Cardoso J. N., Gaskell S. J., Quirk M. M., and Eglinton G. (1983) Hydroxy and fatty acid distributions in Rostherne Lake sediment (England). Chem. Geol. 38, 107-128.

Cerniglia C. E. and Perry J. J. (1974) Effect of substrate on the fatty acid composition of hydrocarbons utilizing filamentous fungi. J. Bact. 118, 844-847.

CHANDLER R. F. and HoOPER S. N. (1979) Friedelin and associated triterpenoids. Phytochem. 18, 711-724.

Chibnall A. C., Piper S. H., Polland A., Smith J. A. B., and WILliams E. F. (1931) CCXXVI. The wax constituents of the apple cuticle. Biochem. J. 25, 2095-2110.

CHO K. Y. and SALtON M. R. J. (1966) Fatty acid composition of bacterial membrane and wall lipids. Biochim. Biophys. Acta 116, 73-79.

Chuecas L. and RILEY J. P. (1969) Component fatty acids of the total lipids of some marine phytoplankton. J. Mar. Biol. Assoc. U.K. 49, 97-116.

Clark R. C. and Blumer M. (1967) Distribution of $n$-paraffins in marine organisms and sediments. Limnol. Oceanogr. 12, 79-90.

CONNER R. L., LANDREY J. R., BURNS C. H., and MALLORY F. B. (1968) Cholesterol inhibition of pentacyclic triterpenoid biosynthesis in Tetrahymena pyriformis. J. Protozool. 15, 600-605.

Cox R. E., Maxwell J. R., ACKMan R. G., and Hlooper S. N. (1972) The isolation of a series of acyclic isoprenoid alcohols from an ancient sediment: Approaches to a study of the diagenesis and maturation of phytol. In Advances in Organic Geochemistry 1971, (eds. H. R. vON GAERTNER and H. WEHNER), pp. 263-276. Pergamon Press.
CranWEll P. A. (1980) Branched/cyclic alkanols in lacustrine sediments (Great Britain): Recognition of iso- and anteiso-branching and stereochemical analysis of homologous alkan-2-ols. Chem. Geol. 30, 15-26.

Cranwell P. A., Eglinton G., and Robinson N. (1987) Lipids of aquatic organisms as potential contributors to lacustrine sediments. II. Org. Geochem. 11, 513-527.

Das M. C. and Mahato S. B. (1983) Triterpenoids. Phytochem. 22, 1071-1095.

Dastillung M. (1976) Lipides de sédiments récents. Ph.D. thesis, Louis Pasteur University, Strasbourg.

DASTILLUNG M. and ALBRECHT B. (1977) $\Delta^{2}$-sterenes as diagenetic intermediates in sediments. Nature 269, 678-679.

Degens E. T., von Herzen R. P., Wong H. K., Deuser W. G., and JANNASCH H. (1973) Lake Kivu: Structure, chemistry and biology of an East African rift lake. Geol. Rundsch. 62, 245-277.

Degens E. T., WONG H. K., KemPE S., and Kurtman F. (1984) A geological study of Lake Van, Eastern Turkey. Geol. Rundsch. 73, 701-734.

DE LEeUW J. W., RIJPSTRA W. I. C., and SCHENCK P. A. (1981) The occurrence and identification of $\mathrm{C} 30, \mathrm{C} 31$, and $\mathrm{C} 32$ alkan-1,15diols and alkan-15-one-1-ols in Unit I and Unit II Black Sea sediments. Geochim. Cosmochim. Acta 45, 2281-2285.

DE Leeuw J. W., Sinninghe Damste J. S., Klok J., SCHENCK P. A., and BoON J. J. (1985) Biogeochemistry of Gavish Sabkha sediments. I. Studies on neutral reducing sugars and lipid moieties by gas-chromatography-mass spectrometry. In Hypersaline Ecosystems (eds. G. M. FRIEDMAN and W. E. KRUMBEIN), pp. 350367. Springer-Verlag.

de Leeuw J. W., Cox C. H., van Graas G., van de Meer F. W., Peakman T. M., BaAs J. M. A., and Van de Graaf B. (1989) Limited double bond isomerization and selective hydrogenation of sterenes during early diagenesis. Geochim. Cosmochim. Acta 53, 903-909.

De Rosa M., Gambacorta A., Minale L., and Bu Lock J. D. (1971) Bacterial triterpenes. Chem. Commun., 619-620.

DidyK B. M., Simoneit B. R. T., BRaSSEll S. C., and Eglinton G. (1978) Organic geochemical indicators of palaeoenvironmental conditions of sedimentation. Nature 272, 216-222.

DOBSON G., WARD D. M., RoBINSON N., and EGLINTON G. (1988) Biogeochemistry of hot spring environments: Extractable lipids of a cyanobacterial mat. Chem. Geol. 68, 155-179.

EDMUNDS K. L. H. and EGLINTON G. (1984) Microbial lipids and carotenoids and their early diagenesis in the Solar Lake laminated microbial mat sequence. In Microbial Mats: Stromatolites (eds. Y. COHEN et al.), pp. 343-389. Alan R. Liss, Inc.

Edmunds K. L. H., Brasell S. C., and Eglinton G. (1980) The short-term diagenetic fate of $5 \alpha$-cholestan-3 $\beta$-ol: in situ radiolabelled incubation in algal mats. In Advances in Organic Geochemistry 1979 (eds. A. G. Douglas and J. R. MAXWELL), pp. 427434. Pergamon.

EGLINTON G. and HAMILTON R. J. (1967) Leaf epicuticular waxes. Science 156, 1322.

Eglinton G., Hamilton R. J., Martin-Smith M., Smith S. J., and Subramanian G. (1964) Arundoin-a naturally-occurring D:C-friedo-oleana-9(11)-ene. Tetrahedron Lett. 34, 2323-2327.

ENSMINGER A. (1977) Evolution de composés polycycliques sedimentaires. Ph.D. thesis, Louis Pasteur University, Strasbourg.

EVANS R. and KIRKLAND D. W. (1988) Evaporitic environments as a source of petroleum. In Evaporites and Hydrocarbons (ed. B. CH. SCHREIBER), pp. 256-299. Columbia University Press.

EYSSEN H. and VERHULST A. (1984) Biotransformation of linoleic acid and bile acids by Eubacterium lentum. Appl. Env. Microbiol. 47, 39-43.

Farran A., Grimalt J., Albaigés J., Botello A. V., and Macko S. A. (1987) Assessment of petroleum pollution in a Mexican River by molecular markers and carbon isotope ratios. Mar. Pollut. Bull. 18, 284-289.

FARRINGTON J. W. and QUINN J. O. (1973) Biogeochemistry of fatty acids in recent sediments from Narragansett Bay. Rhode Island. Geochim. Cosmochim. Acta 37, 259-268.

Forster H. J., BiemanN K., Haigh W. G., Tattrie N. H., and 
Colvin J, R. (1973) The structure of novel C35 pentacyclic terpenes from Acetobacter xylium. Biochem. J. 135, 133-143.

FuLCO A. J., LEVY R., and BLOCH K. (1964) The biosynthesis of $\Delta^{9}$ and $\Delta^{5}$ monounsaturated fatty acids by bacteria. J. Biol. Chem. 239, 998-1003.

GASKELl S. J. and EGLINTON G. (1975) Rapid hydrogenation of sterols in a contemporary lacustrine sediment. Nature 254, 209212.

GELPI E., ORo J., SCHNEIDER H. J., and BENNETT E. O. (1968) Olefins of high molecular weight in two microscopic algae. Science $161,700-702$.

GELPI E., SCHNEIDER H., MANN J., and ORO J. (1970) Hydrocarbons of geochemical significance in microscopic algae. Phytochem. 9 , 603-612.

Giger W., SChaffNer C., and WakehaM S. G. (1980) Aliphatic and olefinic hydrocarbons in recent sediments of Greifensee, Switzerland. Geochim. Cosmochim. Acta 44, 119-129.

GiLlan F. T. and SANDSTROM M. W. (1985) Microbial lipids from a near shore sediment from Bowling Green Bay, North Queensland: The fatty acid composition of intact lipid fractions. Org. Geochem. $8,321-328$.

Gillan F. T., Johns R. B., Verheyen T. V., Nichols P. D., EsDAILE R. J., and BAVOR H. J. (1983) Monounsaturated fatty acids as specific bacterial markers in marine sediments. In Advances in Organic Geochemistry 1981 (ed. M. BJøROY et al.), pp. 198-206. J. Wiley.

Golterman H. L. and Clymo R. (1969) Methods for Chemical Analysis of Freshwater. I.B.P. Handbook, Blackwell.

GORGEN C. and BOLAND W. (1989) Biosynthesis of 1-alkenes in higher plants: Stereochemical implications. A model study with Carthamus tinctorius (Asteraceae). Eur. J. Biochem. 185, 237242.

Granados M., Vicente A., and GaRCIA F. (1988) Long-term vegetation changes on the stabilized dunes of Doñana National Park (S.W. Spain). Vegetatio 75, 73-80.

GRANT W. D. and LONG P. E. (1985) Environmental microbiology. In The Handbook of Environmental Chemistry. (ed. O. HuTzINGER), Part D, pp. 125-237. Springer-Verlag.

Grimalt J. O. and Albaiges J. (1990) Characterization of the depositional environments of the Ebro delta through the study of sedimentary lipid markers. Mar. Geol. 95, 207-224.

Grimalt J. O., Fernandez P., Bayona J. M., and Albaigés J. (1990) Assessment of fecal sterols and ketones as indicators of urban sewage inputs to coastal waters. Environ. Sci. Tech. 24, 357362.

HAN J. and CalviN M. (1969) Hydrocarbon distribution of algae and bacteria and microbiological activity in sediments. Proc. Natl. Acad. Sci. USA 64, 436-445.

Han J., MCCarthy E. D., Hoeven W. van, Calvin M., and BRADLEY W. H. (1968) Organic geochemical studies, II. A preliminary report on the distribution of aliphatic hydrocarbons in algae, in bacteria, and in a recent lake sediment. Proc. Natl. Acad. Sci. USA 59, 29-33.

Hatcher P. G., Simoneit B. R. T., Mackenzie F. T., NeumanN A. C., ThORSTENSON D. C., and GERCHAKOV S. M. (1983) Organic geochemistry and pore water chemistry of sediments from Mangrove Lake, Bermuda. Org. Geochem. 4, 93-112.

Holland H. L. and Diakow P. R. P. (1979) Microbial hydroxylations of steroids. 5. Metabolism of androst-5-en-3,17-dione and related compounds by Rhizopus arrhizus ATCC 11145. Canadian J. Chem. 57, 436-440.

Howard D. H., Simoneit B. R. T., and Chapman D. J. (1984) Triterpenoids from lipids of Rhodomicrobium vannielii. Arch. Microbiol. 137, 200-204.

HUNG J. G. C. and WALKER R. W. (1970) Unsaturated fatty acids of Mycobacteria. Lipids 5, 720-722.

IK.AN P., BAEDECKER M. J., and KAPLAN I. R. (1973). C 18 -isoprenoid ketone in recent marine sediments. Nature 244, 154-155.

IKAN R., BAFDECKER M. J., and KAPLAN I. R. (1975) Thermal alteration experiments on organic matter in recent sediment. II. Isoprenoids. Geochim. Cosmochim. Acta 39, 187-194.

ImHOFF J. F., SaHL H. G., SOliman G. S. H., and Truper H. G.
(1979) The Wadi Natrum: Chemical composition and microbial mass developments in alkaline brines of eutrophic desert lakes. Geomicrob. J. 1, 219-234.

Johns R. B., Belsky T., McCarthy E. D., BuRlingame A. L., Haug P., SChNoes H. K., RiChTER W., and CAlvin M. (1966) The organic geochemistry of ancient sediments. II. Geochim. Cosmochim. Acta 30, 1191-1222.

JulaK J., TURECEK F., and Mikova Z. (1980) Identification of characteristic branched-chain fatty acids of Mycobacterium kansasii and gordonae by gas chromatography-mass spectrometry. $J$. Chromatogr. 190, 183-187.

KANEDA T. (1967) Fatty acids in the genus Bacillus. I. Iso- and anteiso-fatty acids as characteristic constituents of lipids in 10 species. J. Bacteriol. 93, 894-903.

KATES M. (1978) The phytanyl ether-linked polar lipids and isoprenoid neutral lipids of extremely halophilic bacteria. Chem. Fats Lipids 15, 301-342.

KELTS K. (1988) Environments of deposition of lacustrine petroleum source rocks: An introduction. In Lacustrine Petroleum Source Rocks (eds. A. J. FleET et al.); Geol. Soc. Spec. Publ. 40, pp. 326.

KEMP P., LANDER D. J., and ORPIN C. G. (1984) The lipids of the rumen fungus Piromonas communis. J. Gen. Microbiol. 130, $27-$ 37.

Kleemann G., Poralla K., Englert G., Huosen H., LiaaenJENSEN S., Neulist S., and Rohmer M. (1990) Tetrahymanol from the phototrophic bacterium Rhodopseudomonas palustris: First report on a gammacerane triterpene from a prokaryote. $J$. Gen. Microbiol. 136, 2551-2553.

KOHLHASE M. and POHL P. (1988) Saturated and unsaturated sterols of nitrogen-fixing blue-green algae (Cyanobacteria). Phytochem. 27, 1735-1740.

KOLATTUKUDY P. E. (1970) Plant waxes. Lipids 5, 259-275.

Kushwaha S. C., Juez-Perez G., RodRiguez-Valera F., Kates M., and KUSHNER D. J. (1982) Survey of lipids of a new group of extremely halophilic bacteria from salt ponds in Spain. Canadian J. Microbiol. 28, 1365-1372.

LAFlamme R. E. and Hites R. A. (1979) Tetra- and pentacyclic, naturally-occurring, aromatic hydrocarbons in recent sediments. Geochim. Cosmochim. Acta. 43, 1687-1691.

LANGWORTHY T. A., Tornabene T. G., and Holzer J. (1982) Lipids of archaebacteria. Zbl. Bakt. Hyg., I. Abt. Orig. C3, 228244.

LYTLE T. F., LyTLE J. S., and CARUSO A. (1976) Hydrocarbons and fatty acids of ferns. Phytochem. 15, 965-970.

MAKULA R. A. (1978) Phospholipid composition of methane-utilizing bacteria. J. Bacteriol. 14, 771-777.

MARTZ R. F., Sebacher D. I., and White D. C. (1983) Biomass measurement of methane forming bacteria in environmental samples. J. Microbiol. Methods 1, 53-61.

MATSUDA H. and KOYAMA T. (1977) Early diagenesis of fatty acids in lacustrine sediments. I. Identification and distribution of fatty acids in recent sediments from a freshwater lake. Geochim. Cosmochim. Acta 41, 341-345.

Matsumoto G. I., AKiYama M., Watanuki K., and Tori T. (1990) Unusual distribution of long-chain $n$-alkanes and $n$-alkenes in Antarctic soil. Org. Geochem. 15, 403-412.

MELACK J. M. (1981) Photosynthetic activity of phytoplankton in tropical African soda lakes. Hydrobiol. 81, 71-85.

MERMOUd F., WunSCHE L., CleRC O., GulaCAR F. O., and Buchs A. (1984) Steroidal ketones in the early diagenetic transformations of sterols in different types of sediments. Org. Geochem. 6, 25-29.

MLADENOVA K., YochKova Y. A., and Stolanova-IVANOVA B. (1983) Wax composition of the Kazalik and Damask roses. Phytochem. 22, 943-945.

MORRIS R. J. and BRASSELL S. C. (1988) Long chain alkanediols: Biological markers for cyanobacterial contributions to sediments. Lipids 23, 256-258.

MURPHY J. and RILEY J. P. (1962) A modified single solution method for the determination of soluble phosphate in natural waters. Anal. Chim. Acta 27, 31-41.

Naccarato W. F., Gelman R. A., Kawalek J. C., and Gilbert- 
SON J. R. (1972) Characterization and metabolism of free fatty alcohols from Escherichia coli. Lipids 7, 275-281.

NES W. R. and MCKEAN M. L. (1977) Biochemistry of Steroids and Other Isoprenoids. University Park Press.

NetTing A. G. and MACEY M. J. K. (1971) The composition of ketones and secondary alcohols from Brassica oleracea waxes. Phytochem. 10, 1917-1920.

Nichols P. D., Volkman J. K., Palmisano A. C., Smith G. A., and WHITE D. C. (1988) Occurrence of an isoprenoid $C_{25}$ diunsaturated alkene and high neutral lipid content in Antarctic Seaice diatom communities. J. Phycol. 24, 90-96.

Nichois P. D., Palmisano A. C., Rayner M. S., Smith G. A., and WHITE D. C. (1990) Occurrence of novel $C_{30}$ sterols in Antarctic sea-ice diatom communities during a spring bloom. Org. Geochem. 15, 503-508.

Nishimoto K., ITo M., NATERI S., and OHMOto T. (1968) The structures of arundoin, cylindrin and fernenol. Triterpenoids of fernane and arborane groups of Imperata cylindrica var. Koenigu. Tetrahedron 24, 735-752.

NISHIMURA M. (1977) Origin of stanols in young lacustrine sediments. Nature 270, 711-712.

NishimuRa M. and KoYama T. (1977) The occurrence of stanols in various living organisms and the behaviour of sterols in contemporary sediments. Geochim. Cosmochim. Acta 41, 379-385.

OLIVER J. D. and COLWELL R. R. (1973) Extractable lipids of gramnegative marine bacteria: Fatty acid composition. Intl. J. Sys. Bacteriol. 23, 442-458.

OURISSON G., ALBRECHT P., and ROHMER M. (1979) The hopanoids. Paleochemistry and biochemistry of a group of natural products. Pure Appl. Chem. 51, 709-729.

Pant P. and Rastogi R. P. (1979) The triterpenoids. Phytochem. 18, 1095-1108.

Paoletti C., Pushparaj B., Florenzano G., Capella P., and LERCKER G. (1976) Unsaponifiable matter of green and blue-green algal lipids as a factor of biochemical differentiation of their biomasses. II. Terpenic alcohol and sterol fractions. Lipids 11, 266271.

Perez Cabrera J. and ToJ A J. (1989) Introducción al conocimiento de las comunidades de ciliados existentes en la zona de la laguna de Santa Olalla (P. N. de Doñana). Oxyura 5, 5-29.

PIORRECK M. and POHL P. (1984) Formation of biomass, total protein, chlorophylls, lipids and fatty acids in green and blue-green algae during one growth phase. Phytochem. 23, 217-223.

PIORReCK M., BAASCH K-H., and POHL P. (1984) Biomass production total protein, chlorophylls, lipids and fatty acids of freshwater green and blue-green algae under different nitrogen regimes. Phytochem. 23, 207-216.

RequeJo A. G., QuinN J. G., Gearing J. N., and Gearing P. J. (1984) $C_{25}$ and $C_{30}$ biogenic alkenes in a sediment core from the upper anoxic basin of the Pettaquamscutt River (Rhode Island, USA). Org. Geochem. 7, 1-10.

Rezanka T., Vokoun J., Slavicek J., and Podojil M. (1983) Determination of fatty acids in algae by capillary gas chromatography-mass spectrometry. J. Chromatogr. 268, 71-78.

RHEAD M. M., Eglinton G., and DRAFFAN G. H. (1977) Conversion of oleic acid to saturated fatty acids in Severn Estuary sediments. Nature 232, 327-330.

Robinson N., Eglinton G., Brassell S. C., and Cranwell P. A. (1984) Dinoflagellate origin for sedimentary $4 \alpha$-methylsteroids and $5 \alpha$ (H)-stanols. Nature 308, 439-442.

RoBSON J. N. and RowLAND S. J. (1986) Identification of novel widely distributed sedimentary acyclic sesterpenoids. Nature 324, $561-563$.

RoDIER J. (1975) Analysis of Water. J. Wiley.

ROHMER M. and OURISSON G. (1976) Derivés du bacteriohopane: variations structurales et repartition. Tetrahedron Lett., 3637-3640.

RoHMER M., Bouvier-NAVE P., and OURISSON G. (1984) Distribution of hopanoid triterpenes in prokaryotes. J. Gen. Microbiol. 130, 1137-1150.

Rontani J-F., Combe I., and GiRal P. J-P. (1990) Abiotic degradation of free phytol in the water column: A new pathway for the production of acyclic isoprenoids in the marine environment. Geochim. Cosmochim. Acta 54, 1307-1313.

ROWLAND S. J., YON D. A., LEWIS C. A., and MAXWELL J. R. (1985) Occurrence of 2,6,10-trimethyl-7-(3-methylbutyl)-dodecane and related hydrocarbons in the green alga Enteromorpha prolifera and sediments. Org. Geochem. 8, 207-213.

RULLKOTTER J., LANDGRAF M., and Disko U. (1988) Gas chromatographic and mass spectrometric characterization of isomeric alkylthiophenes $\left(\mathrm{C}_{20}\right)$ and their occurrence in Deep Sea sediments. J. High Resoln. Chromatogr. 11, 633-638.

Ryther J. H., Menzel D. W., Hulbert E. M., LoRenzen C. J., and CORWIN N. (1971) The production and utilization of organic matter in the Peru coastal current. Invest. Pesq. 35, 43-59.

SCHEUERBRANDT G. and BLOCH K. (1962) Unsaturated fatty acids in micronrganisms. J. Biol. Chem. 237, 2064-2068.

SimONEIT B. R. T. and MAZUREK M. A. (1982) Organic matter of the trophosphere-II. Natural background of biogenic lipid matter in aerosols over the rural Western United States. Atmos. Environ. 16, 2139-2159.

Sinninghe Damste J. P., Kock-von Dalen A. C., De LeeuW J. W., SChenck P. J., Guoying S., and Brassell S. C. (1987) The identification of mono-, di-, and trimethyl 2-methyl-2-(4,8,12trimethyltridecyl)chromans and their occurrence in the geosphere. Geochim. Cosmuchim. Acta 51, 2393-2400.

SMITH D. J., EGLINTON G., and MORRIS R. J. (1983) Occurrence of long-chain alkan-diols and alkan-15-one-1-ols in a Quaternary sapropel from the eastern Mediterranean. Lipids 18, 902-905.

SORM F., Vollrab V., JAROlimeK P., and Streibl M. (1964) Olefins in plant waxes. Chem. Ind., 1833-1834.

Strickland J. D. H. and Parsons T. R. (1972) A Practical Handbook of seawater analysis; Fish. Res. Board. Canadian Bull. 167.

TALLING J. F. and DRIVER D. (1963) Some problems in the estimation of chlorophyll in phytoplankton. Proc. Conf. Primary Productivity Measurement, Marine and Freshwater; US Atomic Energy Comm. TID-7633, 142-146.

Talling J. F. and TALling I. B. (1965) The chemical composition of African Lake waters. Intl. Rev. Ges. Hydrobiol. 50, 421-463.

TAlling J. F., WOOD R. B., Prosser M. V., and BAXTer R. M. (1973) The upper limit of photosynthetic productivity by phytoplankton: Evidence from Ethiopian soda lakes. Freshwater Biol. 3, 53-76 (1973).

ten Haven H. L., BaAs M., De Leeuw J. W., MaAssen J. M., and SCHENCK P. A. (1987) Organic geochemical characteristics of sediments from the anoxic brine-filled Tyro basin (eastern Mediterranean). Org. Geochem. 11, 605-611.

TEN HAVEN H. L., ROHMER M., Rullkotter J., and Bisseret P. (1989) Tetrahymanol, the most likely precursor of gammacerane, occurs ubiquitously in marine sediments. Geochim. Cosmochim. Acta 53, 3073-3079.

TinDALL B. J. (1988) Prokaryotic life in the alkaline, saline, athalassic environment. In Halophilic Bacteria (ed. F. RODRIGUEZ-VALERA), Vol. I, pp. 31-67. CRC Press.

TOJA J., LOPEZ T., and GABELLONE, N. A. (1991) Limnological comparison between two peridunar ponds in the Donana National Park (Spain). Archiv. Hydrobiol. (in press).

TORNABENE T. G. and LANGWORTHY T. A. (1978) Diphytanyl and dibiphytanyl glycerol ether lipids of methanogenic archaebacteria. Science 203, 51-53.

TORNabene T. G., Wolfe R. S., Balch W. E., Holzer G., FoX G. F., and ORO J. (1978) Phytanyl-glycerol ethers and squalenes in the archaebacterium Methanobacterium thermoautotrophicum. J. Mol. Evol. 11, 259-266.

TORnabene T. G., LANGworthy T. A., Holzer G., and Oro J. (1979) Squalenes, phytanes and other isoprenoids as major neutral lipids of methanogenic and thermoacidophilic "archaebacteria." J. Mol. Evol. 13, 73-83.

Trendel J. M., Lohman F., Kintzinger J. P., Albrecht P., Chiaroni A., Riche C., Cesario M., Guilhem J., and Pascard C. (1989) Identification of des-A-triterpenoid hydrocarbons occurring in surface sediments. Tetrahedron 45, 4471-4476.

UTHERMOLH H. H. (1958) Zür Vervollkommung der Quantitative Phytoplankton Methodik. Mitt. Intl. Vering. Limnol. 9, 1-38. 
VAN LIER J. E. and SMITH L. L. (1970) Autooxidation of cholesterol via hydroperoxide intermediates. J. Org. Chem. 35, 2627-2632.

VenKATESAN M. I. (1988) Diploptene in the Antarctic sediments. Geochim. Cosmochim. Acta 52, 217-222.

VENKATESAN M. I. (1989) Tetrahymanol: Its widespread occurrence and geochemical significance. Geochim. Cosmochim. Acta 53, 3095-3101.

VENKATESAN M. I., RUTH E., and KAPLAN I. R. (1990) Triterpenols from sediments of Santa Monica Basin, Southern California Bight, U.S.A. Org. Geochem. 16, 1015-1024.

VOLKMAN J. K. (1986) A review of sterol markers for marine and terrigenous organic matter. Org. Geochem. 9, 83-99.

Volkman J. K., Gillan F. T., Johns R. B., and EGlinton G. (1981) Sources of neutral lipids in a temperate intertidal sediment. Geochim. Cosmochim. Acta 45, 1817-1828.

Volkman J. K., Allen D. I., Stevenson P. L., and Burton H. R. (1986) Bacterial and algal hydrocarbons in sediments from a saline Antarctic lake, Ace Lake. Org. Geochem. 10, 671-681.

VOLKMAN J. K., NICHOLS P. O., KEARNEY P. S., ROGERS G. I., and JEFFREY S. W. (1989) 4-Methyl sterols and $5 \alpha(\mathrm{H})$-stanols in some Prymnesiophyte microalgae. 14th Intl. Meeting on Organic Geochemistry, Contribution No. 167, Paris, Sept. 18-22.

Volkman J. K., KearNey P., and JefrRey S. W. (1990) A new source of 4-Methyl sterols and $5 \alpha(\mathrm{H})$-stanols in sediments: Prymnesiophyte microalgae of the genus Pavlova. Org. Geochem. 15, 489-497.

Volkman J. K., Neill G. P., Blackman A. J., and FranzmanN P. D. (1991) Unsaturated phytenyl glyceryl ether lipids in halophilic archaebacteria. 14th Intl. Meeting on Organic Geochemistry, Contribution No. 168. Paris, Sept. 18-22.

VOLLENWEIDER R. A. (1969) A Manual on Methods for Measuring Primary Production in Aquatic Environments; I.B.P. Handbook No. 12. Blackwell.

WAKEHAM S. G. (1987) Steroid geochemistry in the oxygen minimum zone of the eastern tropical North Pacific Ocean. Geochim. Cosmochim. Acta 51, 3051-3069.

Wakeham S. G., SchaffNer C., and Giger W. (1980) Polycyclic aromatic hydrocarbons in recent lake sediments. II. Compounds derived from biogenic precursors during early diagenesis. Geochim. Cosmochim. Acta 44, 415-429.

WEETE J. D. (1976) Algal and fungal waxes. In Chemistry and Biochemistry of Natural Waxes (ed. P. E. KOLATTUKUDY), pp. 349418. Elsevier.

WolfF G. A., Trendel J. M., and Albrecht P. (1989) Novel monoaromatic triterpenoid hydrocarbons occurring in sediments. Tetrahedron 45, 6721-6728.

WOOD B. J. B., NichOLS B. W., and JAmES A. T. (1965) The lipids and fatty acid metabolism of photosynthetic bacteria. Biochim. Biophys. Acta 106, 261-273.

YRUELA I., BARBE A., and GRIMALT J. O. (1990) Determination of double bond position and geometry on linear and highly branched hydrocarbons and fatty acids from gas chromatography/mass spectrometry of epoxides and diols generated by stereospecific resin hydration. J. Chromatogr. Sci. 28, 421-427.

Zander J. M., Caspi E., Pandey G. N., and Mitra C. R. (1969) The presence of tetrahymanol in Oleandra wallichii. Phytochem. 8, 2265-2267. 
STRUCTURES CITED IN TEXT
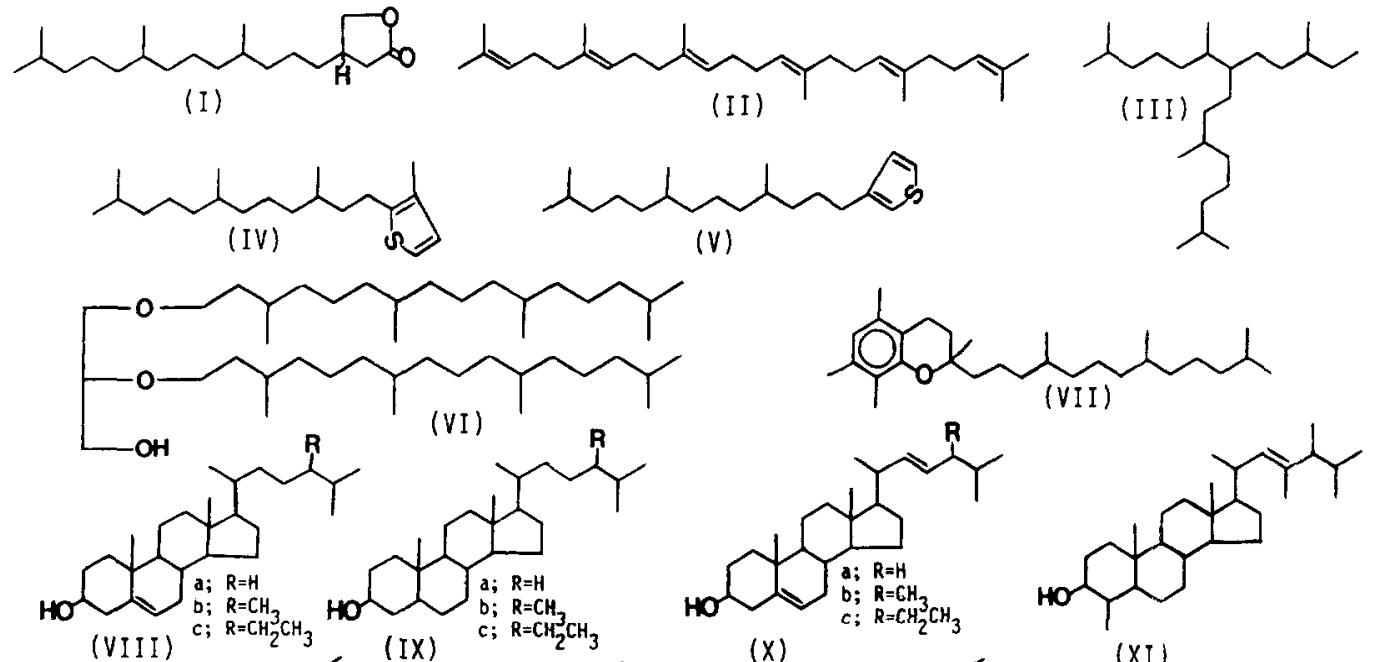

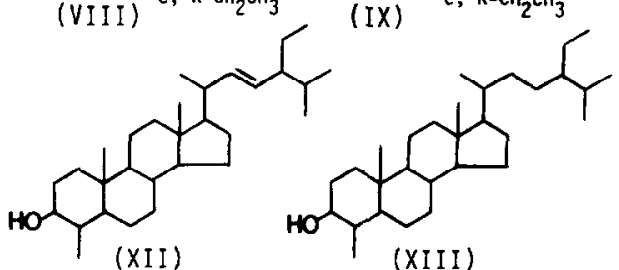

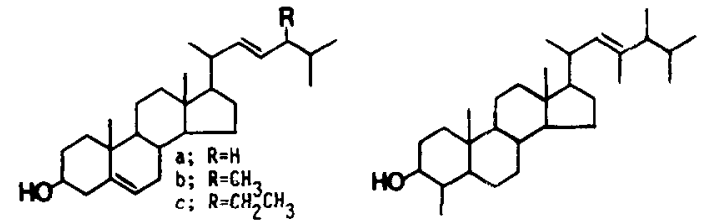

(X)

(XI)<smiles>CCC(CCC(C)C1CCC2C3CCC4C(C)C(=O)CCC4(C)C3CCC12C)C(C)C</smiles>

<smiles>[R]C(C)C(C)CCC(C)C1CCC2C1CCC1C3(C)CC=CCC3CC3(C)CCCCC213</smiles>

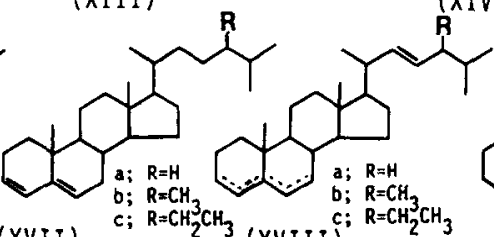

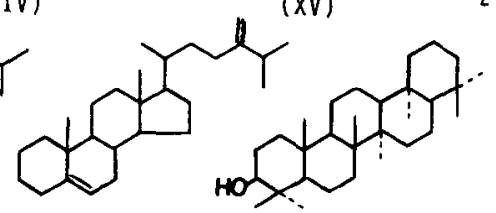
(XVI) $\quad \mathrm{C} ; \mathrm{R}=\mathrm{CH}_{2} \mathrm{CH}_{3}$ (XVII) ${ }^{\mathrm{C} ; \mathrm{R}=\mathrm{CH}_{2}^{3} \mathrm{CH}_{3}}(X V I I I)^{C ;} \mathrm{R}_{2} \mathrm{CH}_{2}^{3} \mathrm{CH}_{3}$ (XIX)

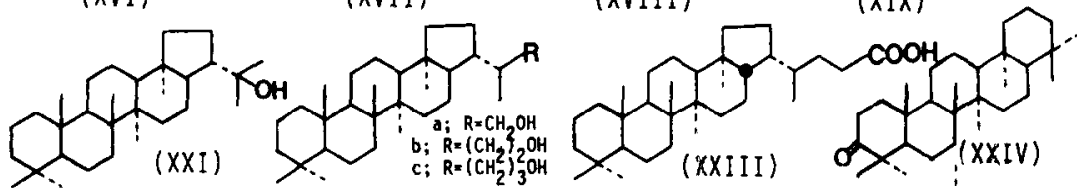

$(x x)$
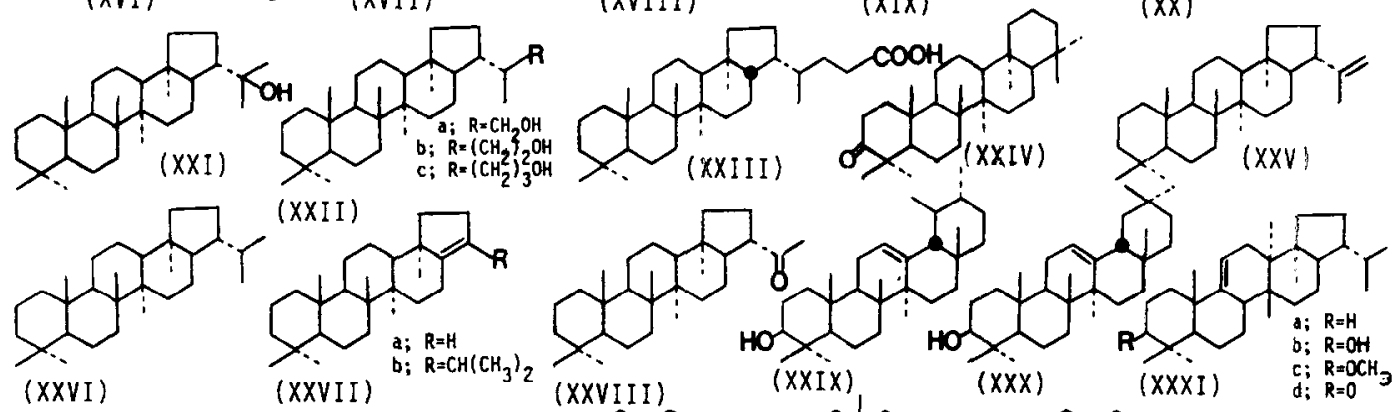

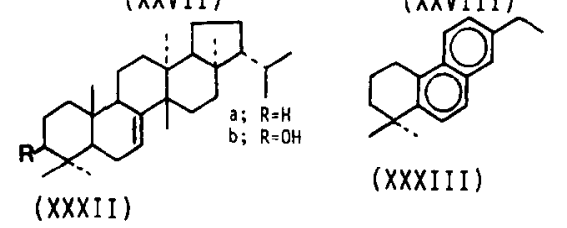

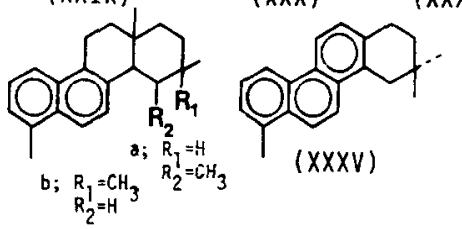

$(X X X I V)$ 